\title{
Phytoplankton size class in the East China Sea derived from MODIS satellite data
}

\author{
Hailong Zhang ${ }^{1,2}$, Shengqiang Wang ${ }^{1,2}$, Zhongfeng Qiu ${ }^{1,2}$, Deyong Sun ${ }^{1,2}$, Joji Ishizaka ${ }^{3}$, Shaojie Sun ${ }^{4}$, and \\ Yijun $\mathbf{H e}^{1,2}$ \\ ${ }^{1}$ School of Marine Sciences, Nanjing University of Information Science \& Technology, Nanjing, Jiangsu, China \\ ${ }^{2}$ Jiangsu Research Centre for Ocean Survey Technology, NUIST, Nanjing, Jiangsu, China \\ ${ }^{3}$ Institute for Space-Earth Environmental Research, Nagoya University, Nagoya, Japan \\ ${ }^{4}$ College of Marine Science, University of South Florida, St. Petersburg, Florida, USA
}

Correspondence: Zhongfeng Qiu (zhongfeng.qiu@nuist.edu.cn)

Received: 28 November 2017 - Discussion started: 5 February 2018

Revised: 28 May 2018 - Accepted: 29 June 2018 - Published: 13 July 2018

\begin{abstract}
The distribution and variation of phytoplankton size class (PSC) are key to understanding ocean biogeochemical processes and ecosystems. Remote sensing of the PSC in the East China Sea (ECS) remains a challenge, although many algorithms have been developed to estimate PSC. Here based on a local dataset from the ECS, a regional model was tuned to estimate the PSC from the spectral features of normalized phytoplankton absorption $\left(a_{\mathrm{ph}}\right)$ using a principal component analysis approach. Before applying the refined PSC model to MODIS (Moderate Resolution Imaging Spectroradiometer) data, reconstructing satellite remote sensing reflectance $\left(R_{\mathrm{rs}}\right)$ at 412 and $443 \mathrm{~nm}$ was critical through modeling them from $R_{\mathrm{rs}}$ between 469 and $555 \mathrm{~nm}$ using multiple regression analysis. Satellite-derived PSC results compared well with those derived from pigment composition, which demonstrated the potential of satellite ocean color data to estimate PSC distributions in the ECS from space. Application of the refined PSC model to the reconstructed MODIS data from 2003 to 2016 yielded the seasonal distributions of the PSC in the ECS, suggesting that the PSC distributions were heterogeneous in both temporal and spatial scales. Micro-phytoplankton were dominant in coastal waters throughout the year, especially in the Changjiang estuary. For the middle shelf region, the seasonal shifts from the dominance of micro- and nano-phytoplankton in the winter and spring to the dominance of nano- and pico-phytoplankton in the summer and autumn were observed. Pico-phytoplankton were especially dominant in the Kuroshio region in the spring, summer, and autumn. The sea-
\end{abstract}

sonal variations of the PSC in the ECS were probably affected by a combination of the water column stability, upwelling, sea surface temperature, and the Kuroshio. Additionally, human activity and riverine discharge might also influence the PSC distribution in the ECS, especially in the coastal region.

\section{Introduction}

Phytoplankton size class (PSC) is fundamentally important for ocean biogeochemical processes and ecosystems, especially for photosynthesis efficiency (Bouman et al., 2005; Uitz et al., 2008), primary production, and the carbon transport (Kiørboe, 1993; Guidi et al., 2009; Hirawake et al., 2011). Thus, knowledge of the PSC dynamics can contribute to the improvement of our understanding of marine ecological and biogeochemical cycles. The classical size fractions of phytoplankton proposed by Sieburth et al. (1978) include three classes, namely, micro- $(>20 \mu \mathrm{m})$, nano- $(2-20 \mu \mathrm{m})$, and pico-phytoplankton $(<2 \mu \mathrm{m})$. Among the methods to measure PSC from water samples, including microscopy (Montagnes et al., 1994), the Coulter counter method (Sheldon and Parsons, 1967), and flow cytometry (Sun et al., 2000), pigment concentration by high-performance liquid chromatography (HPLC) is the most systematic and qualitycontrolled method (Van Heukelem and Hooker, 2011). However, these methods are time-consuming and methodologically complex. Furthermore, large spatial and temporal vari- 
abilities make it difficult to continuously monitor PSC using the field sampling methods.

Realistically, satellite ocean color data can provide synoptic observations, which are ideal for investigating PSC at large spatial and temporal scales. In recent years, various algorithms have been designed to estimate PSC using in situ data and ocean color data on both global and regional scales (IOCCG, 2014). Most algorithms can be partitioned into two categories, namely, "abundance-based" and "spectral-based" methods. The "abundance-based" methods are based on the statistical relationship between phytoplankton size fraction and phytoplankton abundance using measurements such as chlorophyll $a$ concentration (Chl $a$ ) (refer to Bracher et al., 2017, Table 2). These approaches rely on the assumption that high and low Chl $a$ waters are dominated by large and small phytoplankton, respectively. The "spectral-based" methods utilize the relationship between the variations in inherent optical properties with changes in the PSC using measurements such as phytoplankton absorption $\left(a_{\mathrm{ph}}\right)$, remote sensing reflectance $\left(R_{\mathrm{rs}}\right)$, and particulate backscattering $\left(b_{\mathrm{bp}}\right)$ (refer to Bracher et al., 2017, Table 2).

The East China Sea (ECS) is the base of the marine fishery resources in China and is one of the most productive ocean areas in the world (Furuya et al., 1996). Ascertaining the distribution of PSC can provide valuable information on the state of the marine ecosystem and primary production in the area. Recent efforts have been focused on investigating the phytoplankton community and size classes in the ECS and have suggested that the PSC exhibited obvious spatiotemporal heterogeneity in this region ( $\mathrm{Li}$ et al., 2007; Luan et al., 2007; Jiang et al., 2014). For instance, Chen (2000) investigated the PSC and primary productivity in the marginal regions of the southern ECS using field data. The results showed that the phytoplankton size structure and their contributions to primary production displayed significant spatial differences in the shelf waters, upwelling waters, and Kuroshio water. Furuya et al. (2003) presented the phytoplankton dynamics in the ECS in the spring of 1994 and the summer of 1996 using HPLC-derived pigment signatures. A distinct horizontal heterogeneity in phytoplankton composition was observed in the spring, and a "two-layer" distribution of phytoplankton appeared both off and on the shelf in the summer. Liu et al. (2016) used 7-year (2006-2012) field measurements to investigate the seasonal and spatial variations of major phytoplankton groups in the ECS, and found that monsoon forcing was a key factor in impacting phytoplankton dynamics at the seasonal scale.

Note that previous investigations on the PSC in the ECS have been conducted based on field observations, which may not reflect the real variation patterns of PSC. To our knowledge, no study has attempted to examine the PSC distributions in the ECS at synoptic scales from satellite observations. Consequently, the PSC dynamics in the ECS at different spatial and temporal scales and their mechanisms are still poorly understood. In the ECS, Wang et al. (2014) found that the correlation between the variation patterns of the PSC and total Chl $a$ was not valid, and pointed out that the "abundance-based" methods for estimating PSC were probably not applicable in the ECS. Therefore, Wang et al. (2015) proposed a model to estimate the PSC in the ECS using the spectral shape of normalized $a_{\mathrm{ph}}(\lambda)$ through principal component analysis (PCA). This model showed good performance for estimating the PSC from both in situ measured $a_{\mathrm{ph}}$ and $R_{\mathrm{rs}}$. However, this model was developed using a field dataset mainly from offshore waters of the ECS and off the coast of Japan; more importantly, the Wang et al. (2015) model has not been implemented in satellite data yet.

Therefore, the goals of this study were to (1) refine the Wang et al. (2015) model for regional application in the ECS using an extensive dataset covering highly varied water conditions and various seasons, (2) apply the refined PSC model to Moderate Resolution Imaging Spectroradiometer (MODIS) satellite data, and (3) then preliminarily investigate previously unknown seasonal and spatial variation patterns of the PSC in the ECS.

\section{Materials and methods}

\subsection{Study area and sampling stations}

The East China Sea is one of the largest marginal seas in the western North Pacific and is bounded by China, Korea, and Japan (Fig. 1a). Nearly $70 \%$ of the ECS is occupied by a continental shelf shallower than $200 \mathrm{~m}$. Numerous rivers flow into the ECS from mainland China, including the Changjiang (Yangtze) River which provides nearly $90 \%$ of the riverine discharge to the ECS (Zhang et al., 2007). In addition, the ECS experiences strong currents and multiple water masses, such as Changjiang diluted water (CDW), shelf mixed water, and the Kuroshio (Ichikawa and Beardsley, 2002; Su and Yuan, 2005). Here we analyzed the mean shape and coefficient of variation $(\mathrm{CV})$ of in situ $R_{\mathrm{rs}}(\lambda)$ collected in the ECS, to better show the ocean color variability in the ECS which covers many water types (Fig. 2). The in situ $R_{\mathrm{rs}}(\lambda)$ of all samples exhibited large variability in both magnitudes and spectral shapes (Fig. 2a and b). For the samples in the coastal region of Zhejiang (Zhe) and Fujian (Min), all 10 wavebands showed larger variability in $R_{\mathrm{rS}}(\lambda)$ magnitude, with CV larger than $55 \%$ (Fig. 2c). For the samples in southern Jeju, CV varied from 20 to $60 \%$, with a minimum around $531 \mathrm{~nm}$ and $547 \mathrm{~nm}$ (Fig. 2d). Overall, they showed a large dynamic range with significant variability. Because of highly variable environmental conditions, the ECS exhibits complex marine biogeochemical processes and ecosystems.

The field measurements used in this study were collected from approximately 10 cruises over the last decade. These sampling stations were distributed irregularly in the ECS and a few were in the Tsushima Strait (Fig. 1a). The field dataset encompassed various seasons and environmental conditions 

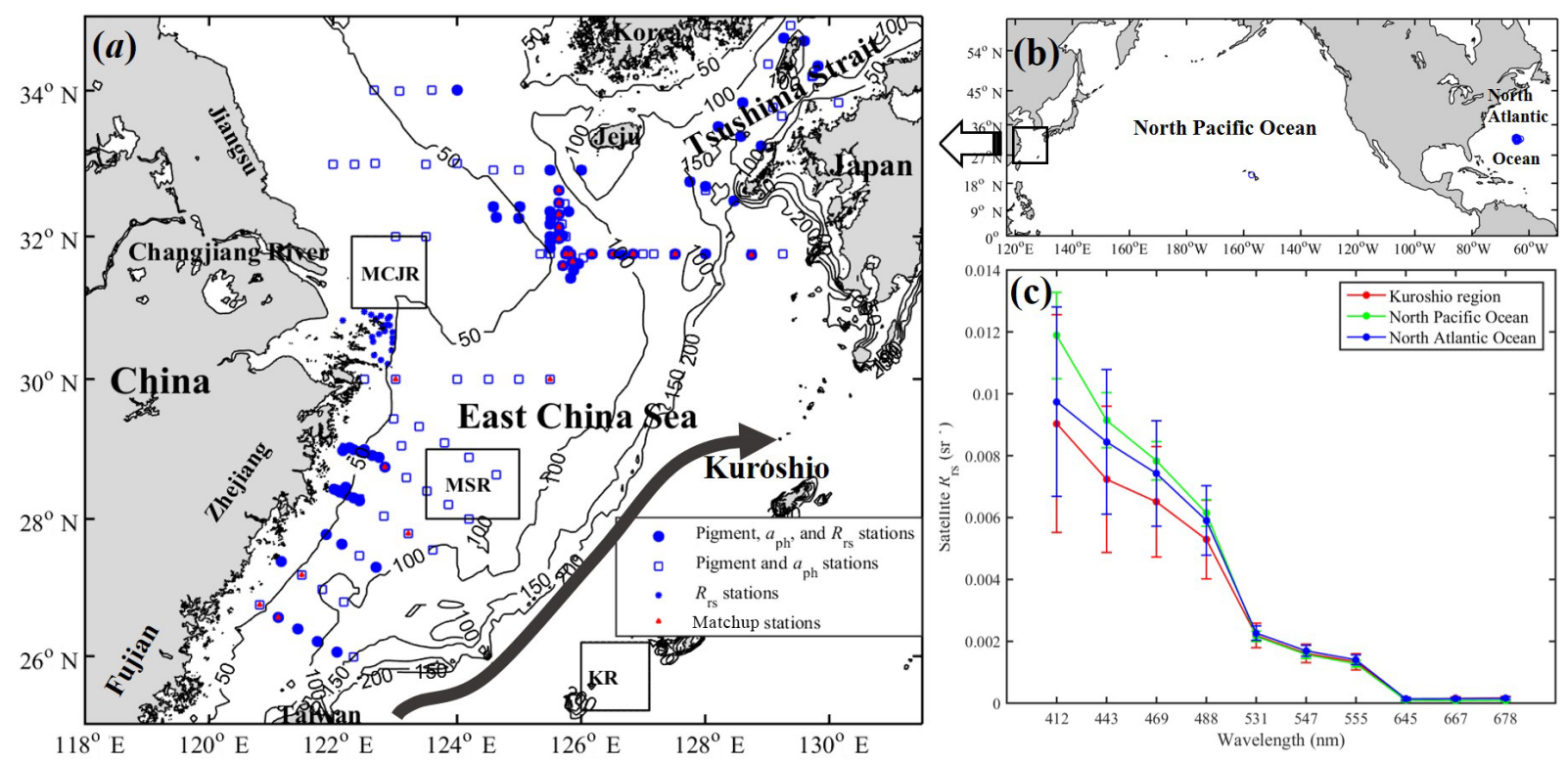

Figure 1. Distribution of in situ and matchup datasets and locations of the selected subareas (black boxes) (a), namely MCJR (mouth area of the Changjiang River), MSR (middle shelf region), and KR (Kuroshio region); locations of sampling stations collected in the North Pacific and North Atlantic oceans from the NASA SeaBASS archive (b); the average satellite $R_{\mathrm{rs}}(\lambda)$ spectra from 2003 to 2016 in the Kuroshio region, North Pacific Ocean, and North Atlantic Ocean (blue circles in b) (c). Error bars represent standard deviations of the means.

of the ocean, including turbid waters in the mouth area of the Changjiang River, less turbid coastal water, and clear water away from the coast. This field dataset consisted of in situ measured $a_{\mathrm{ph}}(\lambda)$, measured $R_{\mathrm{rs}}(\lambda)$ data, and phytoplankton pigments measured by HPLC. In total, 69 samples with synchronous measurements of pigments, $a_{\mathrm{ph}}$, and $R_{\mathrm{rs}}$ data, 101 samples with coincident pigments and measured $a_{\mathrm{ph}}$ data, and 27 samples with only measured $R_{\mathrm{rs}}$ were available, and Fig. 1a shows the spatial distribution of samples. The Kuroshio water in our study area suffered from a paucity of in situ $R_{\mathrm{rs}}$ data. Hence, in addition to the regional dataset, 227 in situ $R_{\mathrm{rs}}$ samples collected in the North Pacific and North Atlantic oceans (Fig. 1b) from the NASA SeaBASS archive were used as a supplementary dataset. The SeaBASS dataset was only used for algorithm development to reconstruct satellite $R_{\mathrm{rS}}$ data, along with our regional field dataset (see Sect. 2.4). The average spectral shapes of the 14-year (2003-2016) MODIS $R_{\mathrm{rs}}$ data in the North Pacific and North Atlantic oceans were similar to that in the Kuroshio water (Fig. 1c). Thus, in situ measured $R_{\mathrm{rs}}$ data collected in the North Pacific and North Atlantic oceans were used in the present study, although the distribution regions of these data were beyond our study area.

Meanwhile, three specific subareas were selected for further investigation in this study, including the mouth area of the Changjiang River (MCJR, 122.3-123.5 $\mathrm{E}$ and 31$32^{\circ} \mathrm{N}$ ), middle shelf region (MSR, $123.5-125^{\circ} \mathrm{E}$ and 28 $29^{\circ} \mathrm{N}$ ), and Kuroshio region (KR, $126-127.1^{\circ} \mathrm{E}$ and $25.2-$ $26.2^{\circ} \mathrm{N}$ ), as marked by black boxes in Fig. 1a. These subar- eas were selected based on geographical locations and driving forces. Within each subarea, the averages of all valid values were calculated for further analysis.

\subsection{In situ measurements}

Surface water samples $(0-3 \mathrm{~m})$ were collected with Niskin samplers mounted on a CTD rosette or a clean bucket. These water samples were used for measurements of $a_{\mathrm{ph}}(\lambda)$ and pigment concentrations.

\subsubsection{Measurement and analysis of HPLC-derived PSC}

For pigment analysis, seawater samples were filtered onto $47 \mathrm{~mm}$ Whatman GF/F glass fiber filters under gentle pressure $(<0.01 \mathrm{MPa})$, and then stored initially on board in liquid nitrogen $\left(-70^{\circ} \mathrm{C}\right)$ for later analysis in the laboratory. Briefly, the concentrations of 19 pigments were determined by reverse-phase HPLC following Van Heukelem and Thomas (2001). To remove measurements with lower precision, the quality control (QA) process was applied to the pigment dataset by HPLC according to the rules of Aiken et al. (2009). In our study, the diagnostic pigment analysis (DPA) was applied to compute the PSC values from HPLC pigment data (hereafter called the HPLC-derived PSC). In brief, the DPA approach uses seven diagnostic pigment concentrations to obtain the HPLC-derived PSC, including fucoxanthin $\left(C_{\mathrm{f}}\right)$, peridinin $\left(C_{\mathrm{p}}\right), 19^{\prime}$-hexanoyloxyfucoxanthin $\left(C_{\mathrm{h}}\right), 19^{\prime}$-butanoyloxyfucoxanthin $\left(C_{\mathrm{b}}\right)$, alloxanthin $\left(C_{\mathrm{a}}\right)$, chlorophyll $b\left(C_{\mathrm{Cb}}\right)$, and zeaxanthin $\left(C_{\mathrm{z}}\right)$. The DPA approach 

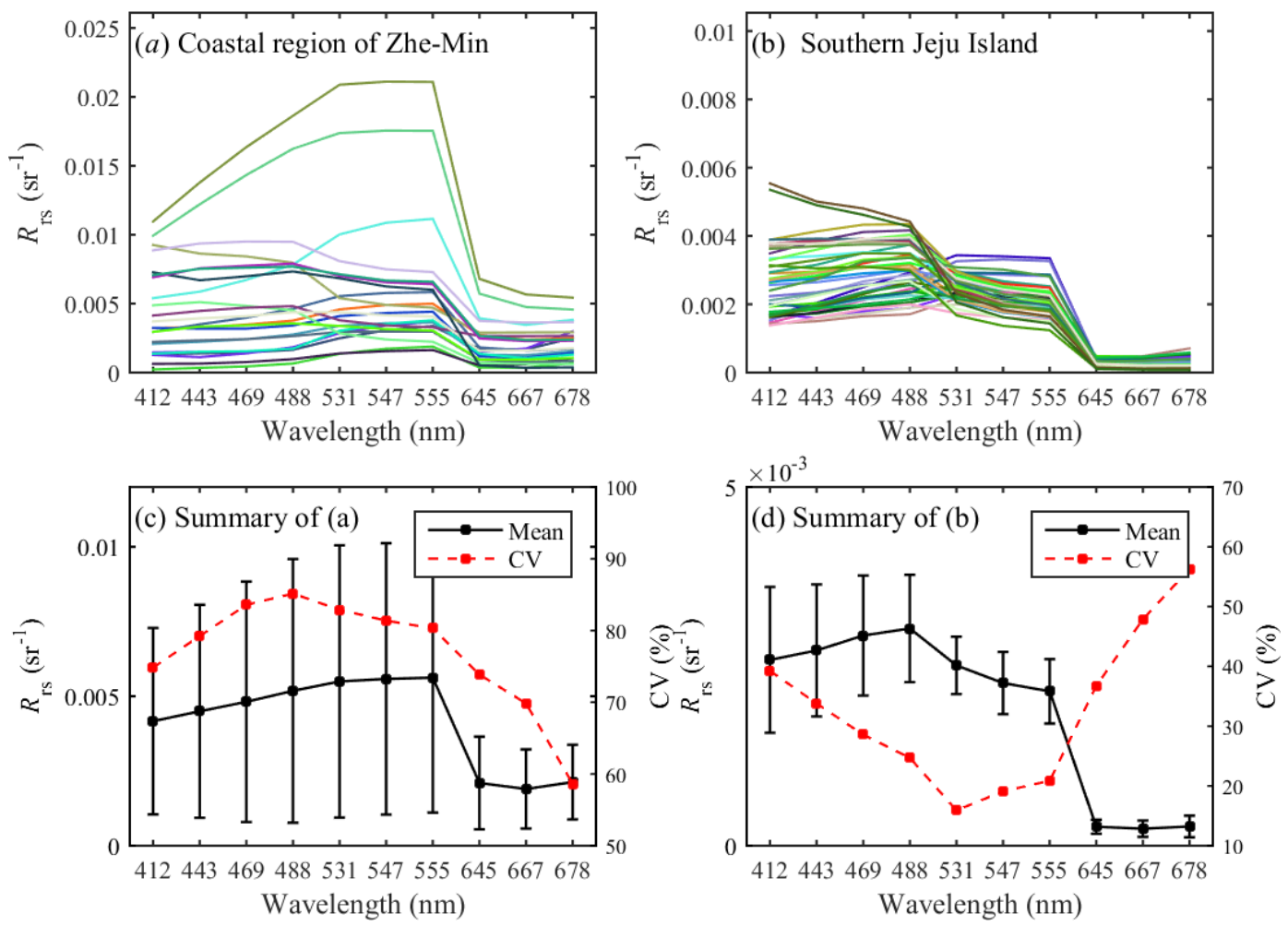

Figure 2. $R_{\mathrm{rs}}(\lambda)$ spectra at MODIS wavelengths collected in the coastal region of Zhe-Min (a) and southern Jeju (b); mean spectra and coefficient of variation $(\mathrm{CV})$ of $R_{\mathrm{rs}}(\lambda)$ in the coastal region of Zhe-Min (c) and southern Jeju (d). The CV is derived as the standard deviation (SD) over the mean.

was originally proposed by Vidussi et al. (2001), and subsequently improved by Uitz et al. (2006). In addition, Hirata et al. (2008) used the improved DPA approach to account for the occurrence of $C_{\mathrm{Cb}}$ in the nano-phytoplankton class, because $C_{\mathrm{Cb}}$ was most abundant at high Chl $a\left(>0.25 \mathrm{mg} \mathrm{m}^{-3}\right)$ and was a minor pigment at lower Chl $a$. Subsequently, Brewin et al. (2010) and Hirata et al. (2011) further refined the DPA approach to account for ambiguity of the $C_{\mathrm{f}}$ signal in diatoms and the occurrence of the $C_{\mathrm{h}}$ signal in picophytoplankton. In this study, the HPLC-derived PSC was then given by

$$
\begin{aligned}
f_{\text {micro }} & =\left(1.41 C_{\mathrm{f}}+1.41 C_{\mathrm{p}}\right) / \sum W_{i} P_{i}, \\
f_{\text {nano }} & =\left(0.60 C_{\mathrm{a}}+0.35 C_{\mathrm{b}}+1.01 C_{\mathrm{Cb}}\right. \\
& \left.+x \times 1.27 C_{\mathrm{h}}\right) / \sum W_{i} P_{i}, \\
f_{\text {pico }} & =\left(0.86 C_{\mathrm{z}}+y \times 1.27 C_{\mathrm{h}}\right) / \sum W_{i} P_{i} .
\end{aligned}
$$

where $f_{\text {micro }}, f_{\text {nano }}$, and $f_{\text {pico }}$ denote the size fractions of micro-, nano-, and pico-phytoplankton, respectively. $x$ and $y$ are the proportions of nano- and pico-phytoplankton in Hex, respectively. When Chl $a>0.08 \mathrm{mg} \mathrm{m}^{-3}, x=1$ and $y=0$; when Chl $a$ is between 0.001 and $0.08 \mathrm{mg} \mathrm{m}^{-3}, x=$ $12.5 \mathrm{Chl} a$ and $y=1-12.5 \mathrm{Chl} a . \sum W_{i} P_{i}$ is the weighted sum of the seven diagnostic pigments (Uitz et al., 2006), ac- cording to the formula

$$
\begin{aligned}
\sum W_{i} P_{i}= & 1.41 C_{\mathrm{f}}+1.41 C_{\mathrm{p}}+0.60 C_{\mathrm{a}}+0.35 C_{\mathrm{b}} \\
& +1.27 C_{\mathrm{h}}+0.86 C_{\mathrm{z}}+1.01 C_{\mathrm{Cb}} .
\end{aligned}
$$

\subsubsection{Measurement of $a_{\mathrm{ph}}$}

To obtain $a_{\text {ph }}$ data, we used the quantitative filter technique (QFT) via a series of processes (Mitchell, 1990). Water samples were filtered through $25 \mathrm{~mm}$ Whatman GF/F glass fiber filters under gentle pressure, and immediately frozen on board in liquid nitrogen. In this study, the "transmittance" approach was used for the samples collected from southern Jeju and the Tsushima Strait (hereafter referred to as dataset1 ). The optical density (OD) values of total particles were measured using a dual-beam multi-purpose spectrophotometer between 350 and $750 \mathrm{~nm}$ at $1 \mathrm{~nm}$ resolution. Similarly, we measured the OD values of the detritus after extracting phytoplankton pigments in methanol for at least $24 \mathrm{~h}$. Meanwhile, a blank filter saturated with pure seawater was used as the reference filter. Then, the absorption coefficients of total particles $a_{\mathrm{p}}(\lambda)$ and detritus $a_{\mathrm{d}}(\lambda)$ were calculated from the corresponding OD values based on a correction of Cleveland and Weidemann (1993). The "transmittancereflectance" approach was performed on the samples collected from the coastal and offshore regions of Zhejiang, Fu- 
jian, and Jiangsu (hereafter referred to as dataset-2). The optical densities of the total particles, detritus, and reference filter were obtained in both transmission mode and reflection mode between 250 and $850 \mathrm{~nm}$ at $1 \mathrm{~nm}$ resolution using a PerkinElmer lamda650s. Then, we converted these OD values into $a_{\mathrm{p}}(\lambda)$ and $a_{\mathrm{d}}(\lambda)$ values using the method of Tassan and Ferrari $(1995,2002)$. Finally, the $a_{\mathrm{ph}}$ data were obtained as the difference of $a_{\mathrm{p}}(\lambda)-a_{\mathrm{d}}(\lambda)$ at all sampling stations.

\subsubsection{Measurement of $R_{\mathrm{rs}}$}

To obtain $R_{\mathrm{rs}}$ data in dataset-1, the PRR-800/811 was used to measure the vertical profiles of the downwelling irradiance $E_{\mathrm{d}}(\lambda, \mathrm{z})$ and upwelling radiance $L_{\mathrm{u}}(\lambda, \mathrm{z})$ at 13 spectral channels $(380,412,443,465,490,510,532,555,565,589,625$, 665 , and $683 \mathrm{~nm})$. The water-leaving radiance $L_{\mathrm{w}}(\lambda)$ was then determined from the profile of $L_{\mathrm{u}}(\lambda, \mathrm{z})$ (Hirawake et al., 2011). The above-water surface downwelling irradiance $E_{\mathrm{d}}\left(\lambda, 0^{+}\right)$was simultaneously measured by a cosine collector. Then, $R_{\mathrm{rs}}(\lambda)$ data were calculated as the ratio of $L_{\mathrm{w}}(\lambda)$ to $E_{\mathrm{d}}\left(\lambda, 0^{+}\right)$. For the purpose of consistency with satellite observations that characterize the oceanic surface layer, our analysis exclusively considered the near-surface $R_{\mathrm{rs}}$ data.

For dataset-2, $R_{\mathrm{rs}}$ data were collected under suitable solar illumination (generally between 09:00 and 15:00 local time) using an ASD FieldSpec spectroradiometer in the spectral range of $350-1050 \mathrm{~nm}$ with $1.5 \mathrm{~nm}$ increments. The radiance spectra of water, sky and a gray reference panel were measured following the above-water measurement approach (Mueller et al., 2003). For each of the three targets, 10 spectra were collected and then averaged after removing abnormal spectra. According to the Ocean Optics Protocol (Mueller et al., 2003), the $R_{\mathrm{rs}}(\lambda)$ data were obtained as

$$
R_{\mathrm{rs}}(\lambda)=\left(L_{t}-\gamma \cdot L_{\mathrm{sky}}\right) /\left(L_{\mathrm{p}} \cdot \pi / \rho_{\mathrm{p}}\right),
$$

where $L_{t}, L_{\mathrm{sky}}$, and $L_{\mathrm{p}}$ correspond to the radiance values measured from the water, sky, and reference panel, respectively. $\rho_{\mathrm{p}}$ is the diffuse reflectance of the reference panel provided by the manufacturer. $\gamma$ is the surface Fresnel reflectance related to wind speed (2.6-2.8\% for $10 \mathrm{~m} \mathrm{~s}^{-1}$ wind, $2.5 \%$ for $<5 \mathrm{~m} \mathrm{~s}^{-1}$ wind, $2.2 \%$ for calm weather) (Tang et al., 2004).

All $R_{\mathrm{rs}}$ and $a_{\mathrm{ph}}$ data were resampled at the centers of MODIS wavebands (i.e., 412, 443, 469, 488, 531, 547, 555, 645,667 , and $678 \mathrm{~nm}$ ) using the spectral response function of the MODIS sensor.

\subsection{Satellite data}

The global standard monthly MODIS remote sensing reflectance, chlorophyll $a$ concentration, and sea surface temperature (SST) products (Level 3, about $4 \mathrm{~km}$ resolution) from 2003 to 2016 were provided by the NASA Ocean Color website (http://oceancolor.gsfc.nasa.gov/, last access: 1 May 2017). The dataset corresponding to our study area $\left(25-35^{\circ} \mathrm{N}\right.$ and $\left.118-132^{\circ} \mathrm{E}\right)$ was extracted from these global coverage datasets. These regional $R_{\mathrm{rs}}$ products were processed using the MathWorks MATLAB software to obtain the satellite-derived PSC. Additionally, daily Level $2 R_{\mathrm{rS}}$ data from the MODIS sensor ( $1 \mathrm{~km}$ resolution) were downloaded from the NASA Ocean Color website.

Samples were matched to daily $R_{\mathrm{rs}}$ data to assess the accuracy of satellite-derived $a_{\mathrm{ph}}$ and PSC results. To ensure the validity of satellite data before the matchup analysis, the following constraints were applied to the matchup dataset: (1) the matchup dataset only included satellite data with an overpass time window within $5 \mathrm{~h}$ before and after the field measurements; (2) to reduce the effect of outliers, the median $R_{\text {rs }}$ value for a window of size 3 centered on the sampling station coordinates was defined as satellite $R_{\mathrm{rs}}$ data; (3) negative MODIS $R_{\mathrm{rs}}$ data were eliminated from the matchup analysis. Based on these criteria, 21 satellite matchups with coincident measured $R_{\mathrm{rs}}$, and 22 satellite matchups with coincident measured PSC and $a_{\mathrm{ph}}$, were available, as shown in Fig. 1a.

\subsection{Model accuracy assessment}

To evaluate the consistency between the derived and measured values, the Pearson correlation coefficient $(R)$, root mean square error (RMSE), and mean absolute percentage error (MAPE) were used. Statistical assessments were performed in $\log _{10}$ space for the phytoplankton absorption coefficient and in linear space for the phytoplankton size class. These statistical indicators can be written as

$$
\begin{aligned}
& \operatorname{RMSE}=\frac{1}{n} \sqrt{\sum_{i=1}^{n}\left[\left(x_{i, \text { derived }}-x_{i}, \text { field }\right) / x_{i}, \text { field }\right]^{2},} \\
& \operatorname{MAPE}(\%)=\frac{1}{n} \sum_{i=1}^{n} \mid\left(x_{i, \text { derived }}-x_{i, \text { field }) / x_{i} \text {, field } \mid}\right. \\
& \quad \times 100 \%,
\end{aligned}
$$

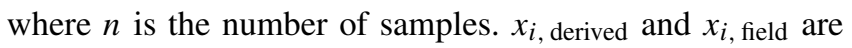
the derived and measured data for the $i$-th sampling station, respectively.

\subsection{Modifying the Wang et al. (2015) model for retrieving PSC}

Wang et al. (2015) developed a spectral-based PSC model to quantify the size fractions of three phytoplankton classes using the spectral shape of $a_{\mathrm{ph}}(\lambda)$ through the PCA approach. Details of the development and parameterization of the model were described in Wang et al. (2015). In brief, to reduce the biomass effects, the normalized $a_{\mathrm{ph}}(\lambda)$ (hereafter called $\left.a_{\mathrm{ph}}^{\mathrm{std}}(\lambda)\right)$ was computed by the ratio of $a_{\mathrm{ph}}(\lambda)$ to their wavelength mean values in the spectral range between 412 and $547 \mathrm{~nm}$. Then, the PCA approach was applied to the $a_{\mathrm{ph}}^{\text {std }}$ $(\lambda)$ to capture the spectral variation in phytoplankton absorption related to cell size. The input of PCA is a $m \times N$ matrix constituted of $a_{\mathrm{ph}}^{\text {std }}(\lambda)$, where $m$ and $N$ are the number 
of input wavelengths and samples, respectively. The output of PCA comprises two terms, i.e., principal component (PC) scores and PC weights (also called loading factors). The PC scores were assumed to correlate with the size class. Therefore, the relationships between the size fractions of microand pico-phytoplankton and PC scores were established using a logistic-type regression model (Hosmer Jr et al., 2013), as follows:

$$
\begin{gathered}
f_{t}=1 /\left[1+\exp \left(-\beta_{0}-\sum_{i=1}^{k} \beta_{i} S_{i}\right)\right] \\
S_{i}=\sum_{j=1}^{m} w_{i j} a_{\mathrm{ph}}^{\mathrm{std}}\left(\lambda_{j}\right)
\end{gathered}
$$

where $f_{t}$ denotes the phytoplankton size fraction $(t=$ micro or pico). $\beta_{0}$ and $\beta_{i}$ are the regression coefficients between $f_{t}$ and PC scores. $k$ is the number of PC scores $(k=4$ in this study). $w_{i j}$ refers to the loading factor for the $i$-th PC. $m$ is the number of wavelengths. Similar to previous studies (Brewin et al., 2010; Hirata et al., 2011), $f_{\text {nano }}$ was calculated as $1-f_{\text {micro }}-f_{\text {pico }}$, by considering that the sum of three phytoplankton size fractions was 1 .

The $a_{\mathrm{ph}}(\lambda)$ at MODIS wavelengths were derived from $R_{\mathrm{rs}}(\lambda)$ data using the quasi-analytical algorithm (QAA) proposed by Lee et al. (2002). QAA was used in this study because it does not suppose a fixed shape for $a_{\mathrm{ph}}(\lambda)$ (Lee et al., 2002 , 2009). Because QAA could give satisfactory retrievals of $a_{\mathrm{ph}}(\lambda)$ at the first six MODIS wavebands (i.e., 412, 443, $469,488,531$, and $547 \mathrm{~nm}$ ), as shown later for details, only $a_{\mathrm{ph}}(\lambda)$ data at these wavebands were used for the PSC model development in this study (i.e., $m=6$ in Eq. 8).

To improve the accuracy of MODIS $R_{\mathrm{rs}}(\lambda)$ at short wavelengths (see details in Sect. 3.3), the reconstruction approach (Lee et al., 2014; Sun et al., 2015) was used to reconstruct satellite $R_{\mathrm{rs}}(\lambda)$ at 412 and $443 \mathrm{~nm}$ before applying the refined PSC model to satellite data. In our study, satellite $R_{\mathrm{rs}}(412)$ and $R_{\mathrm{rs}}(443)$ were quantified as a multivariable linear relationship using $R_{\mathrm{rs}}$ data from 469 to $555 \mathrm{~nm}$, as follows:

$R_{\mathrm{rs}}^{\mathrm{rc}}(\lambda)=\sum_{i=1}^{n} K_{i} R_{\mathrm{rs}}\left(\lambda_{i}\right)+K_{0}$

where $R_{\mathrm{rs}}^{\mathrm{rc}}(\lambda)$ is the reconstructed $R_{\mathrm{rs}}$ data at wavelength $\lambda$ (412 or $443 \mathrm{~nm}$ ); $R_{\mathrm{rs}}\left(\lambda_{i}\right)$ are the input $R_{\mathrm{rs}}$ data at five MODIS wavebands $\left(\lambda_{i}=469,488,531,547\right.$, and $\left.555 \mathrm{~nm}\right) ; K_{0}$ and $K_{i}$ are the coefficients determined from multivariant regression.

\section{Results}

\subsection{Regional tuning of the PSC model for the ECS}

Following Wang et al. (2015), Eq. (8) was fitted to 170 pairs of the HPLC-derived PSC and in situ measured $a_{\mathrm{ph}}$ data using a nonlinear least-squares fitting procedure for developing the PSC model. The established parameters and associated $R$ and RMSE values for each of the fits are shown in Table 1. Figure 3 shows the strong linear relationships between the in situ $a_{\mathrm{ph}}^{\text {std }}$-derived PSC and HPLC-derived results, with $R$ values of $0.89,0.70$, and 0.84 and RMSE values of $0.11,0.11$, and 0.11 for micro-, nano-, and pico-phytoplankton, respectively. The samples were close to the $1: 1$ line, with most of the samples within the $\pm 20 \%$ fraction range.

Using 69 measurements of $R_{\mathrm{rs}}$ and associated HPLCderived PSC and in situ measured $a_{\mathrm{ph}}$, we also examined the feasibility of the PSC model for satellite observations by coupling QAA. First, we used QAA version 5 (QAA_v5) to retrieve $a_{\mathrm{ph}}$ from measured $R_{\mathrm{rs}}$. To assess the performance of QAA_v5, negative retrieved $a_{\mathrm{ph}}$ values were eliminated, and the remainder were compared with the measured values at all MODIS wavebands (Fig. 4). The retrieved $a_{\mathrm{ph}}$ values by QAA_v5 show reasonably good agreement with the in situ measured $a_{\mathrm{ph}}$ at short wavelengths from 412 to $547 \mathrm{~nm}$, with high $R$ values and low RMSE and MAPE values. In contrast, the performance of QAA_v5 was poor and produced large overestimation of $a_{\mathrm{ph}}$ at long wavelengths, especially at 645,667 , and $678 \mathrm{~nm}$, consistent with previous findings (Lee et al., 2014; Tiwari and Shanmugam, 2014). These results clearly demonstrated that QAA_v5 can produce accurate estimates of $a_{\mathrm{ph}}$ at 412, 443, 469, 488, 531, and $547 \mathrm{~nm}$. Therefore, only $a_{\mathrm{ph}}$ values at these bands were used to calibrate the PSC model, as previously stated. Then, the PSC values were inferred from the retrieved $a_{\mathrm{ph}}$ using Eq. (8) with the established parameterizations. As shown in Fig. 5, the QAA $a_{\mathrm{ph}}^{\text {std }}(\lambda)$-derived PSC values were consistent with the HPLCderived results, and almost all of the points fell within the $\pm 20 \%$ fraction range. The $R$ and RMSE values were 0.79 and 0.13 for micro-phytoplankton, 0.43 and 0.12 for nanophytoplankton, and 0.80 and 0.13 for pico-phytoplankton, respectively. These results suggested that the refined PSC model for the ECS coupling QAA_v5 is able to accurately estimate the PSC from remote sensing reflectance $R_{\mathrm{rs}}$.

\subsection{Comparison of satellite $\boldsymbol{R}_{\mathrm{rs}}$ with in situ measurements}

Before applying the PSC model to MODIS data, we assessed the accuracy of MODIS $R_{\mathrm{rs}}$ using the synchronous in situ measurements. Table 2 shows the statistical results of the comparison between satellite $R_{\mathrm{rs}}$ and in situ values for MODIS wavebands. For MODIS $R_{\mathrm{rs}}$ data, a reasonably good consistency was found at green and red bands (from 469 to $555 \mathrm{~nm}$ ), with $R$ values within $0.85-0.97$ and MAPE values within 14.9-27.25\%. Although the $R$ values were above 0.85 , the MAPE values were high $(>54 \%$ ) at 645,667 , and $678 \mathrm{~nm}$. This is probably caused by the lower $R_{\mathrm{rs}}$ values at these bands due to strong absorption of water itself. In addition, a low accuracy was observed at 412 and $443 \mathrm{~nm}$. The $R$ values were 0.46 and 0.73 , and the MAPE values were 47.33 and $36.90 \%$ at 412 and $443 \mathrm{~nm}$, respectively. The high 

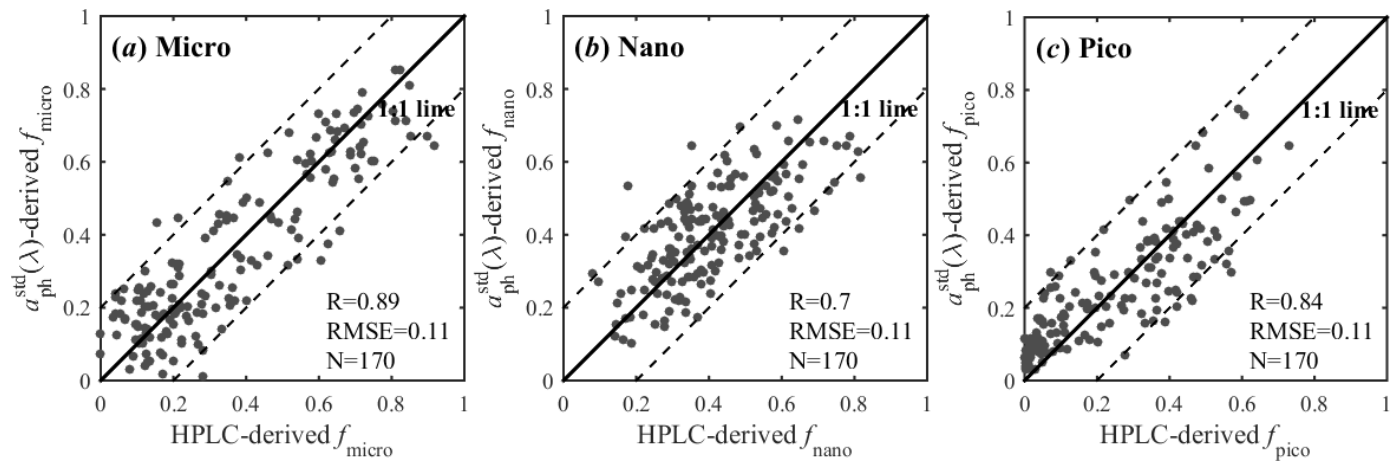

Figure 3. Comparison between in situ $a_{\mathrm{ph}}^{\mathrm{std}}(\lambda)$-derived and HPLC-derived PSC for micro- (a), nano- (b), and pico-phytoplankton (c). Dashed lines represent the $\pm 20 \%$ fraction range relative to the $1: 1$ line.

Table 1. Parameter $\beta_{i}$ values for the PSC model development.

\begin{tabular}{lrrrrrrrr}
\hline Class & $N$ & $R$ & RMSE & $\beta_{0}$ & $\beta_{1}$ & $\beta_{2}$ & $\beta_{3}$ & $\beta_{4}$ \\
\hline Micro & 170 & 0.89 & 0.11 & 1.05 & 3.48 & -4.34 & -13.09 & 16.04 \\
Nano & 170 & 0.70 & 0.11 & - & - & - & - & - \\
Pico & 170 & 0.84 & 0.11 & -2.56 & -1.52 & 1.24 & -25.87 & -1.86 \\
\hline
\end{tabular}

noise and low accuracy at these two wavebands were suggested to be caused by the uncertainty of the atmospheric correction procedures and significant band degradation (Meister, 2011; Hu et al., 2013). Considering the importance of $R_{\mathrm{rs}}(412)$ and $R_{\mathrm{rs}}(443)$ to the QAA algorithm, the poor accuracy of satellite $R_{\mathrm{rs}}$ at these bands may introduce uncertainty into the retrieved $a_{\mathrm{ph}}$ data, and further increase the uncertainty of satellite-derived PSC. Thus, an accurate assessment of satellite-derived PSC requires the improved quality of satellite $R_{\mathrm{rs}}$ data. In this study, the reconstruction approach was used to fulfill this objective.

\subsection{Reconstruction of MODIS $R_{\mathrm{rs}}$ data}

The reconstruction function (Eq. 9) was applied to the regional field dataset and SeaBass dataset to obtain the regression coefficients. The resulting relationships between the in situ measured and modeled $R_{\mathrm{rs}}$ show strong agreement, with high $R^{2}$ and low RMSE and MAPE values (Table 3). For 412 and $443 \mathrm{~nm}$, the $R^{2}$ values were close to 1.0 , with a significance level of $p<0.001$. The MAPE values were both lower than $9.0 \%$. The reconstruction functions with the established coefficients were applied to the original MODIS $R_{\mathrm{rs}}$ data to obtain the reconstructed satellite $R_{\mathrm{rS}}^{\mathrm{rc}}(412)$ and $R_{\mathrm{rS}}^{\mathrm{rc}}(443)$ data. Table 4 shows the comparison of the original satellite $R_{\mathrm{rs}}$ and satellite $R_{\mathrm{rs}}^{\mathrm{rc}}$ data with in situ measured $R_{\mathrm{rs}}$ at 412 and $443 \mathrm{~nm}$. The satellite $R_{\mathrm{rs}}^{\mathrm{rc}}$ data were in better agreement with the in situ measured $R_{\mathrm{rs}}$ data than the original satellite $R_{\mathrm{rs}}$, especially at $412 \mathrm{~nm}$. At $412 \mathrm{~nm}$, the values of $R$, RMSE, and MAPE reached $0.70,0.0019$, and $35.15 \%$ for the satellite $R_{\mathrm{rs}}^{\mathrm{rc}}$ data, respectively, while these values were $0.46,0.0026$, and $47.33 \%$ for the original satellite data, respectively. These re- sults indicated that the accuracy of the satellite $R_{\mathrm{rs}}$ data at 412 and $443 \mathrm{~nm}$ could be improved through reconstruction using the selected MODIS wavebands.

\subsection{Validation of satellite-derived $a_{\mathrm{ph}}$ and PSC with in situ measured data}

Based on the above analysis, we used the satellite $R_{\mathrm{rs}}^{\mathrm{rc}}(412)$ and $R_{\mathrm{rs}}^{\mathrm{rc}}(443)$ data rather than original satellite $R_{\mathrm{rs}}$ data to compute $a_{\mathrm{ph}}$ using QAA_v5. Figure 6 shows the comparison of the derived $a_{\mathrm{ph}}$ data from satellite $R_{\mathrm{rs}}^{\mathrm{rc}}$ (hereafter called $a_{\mathrm{ph}}^{\mathrm{rc}}$ ) and the derived $a_{\mathrm{ph}}$ from original satellite $R_{\mathrm{rs}}$ with in situ measurements at the first six MODIS wavebands. Table 5 summarized their corresponding statistical comparisons, i.e., $R$, RMSE, MAPE, and percentage of valid points (PVP). Here PVP is defined as the ratio of the number of positive satellite-derived values $(n)$ to the total number of matchups $(N)($ as $\mathrm{PVP}=n / N \times 100 \%)$. For the satellite-derived $a_{\mathrm{ph}}^{\mathrm{rc}}$, the $R$ values were above 0.80 , except at $547 \mathrm{~nm}(R=0.69)$, and were significantly higher than those for the satellitederived $a_{\mathrm{ph}}$ (with most of the values below 0.7). The statistics (RMSE, MAPE, and PVP) for the satellite-derived $a_{\mathrm{ph}}^{\text {rc }}$ were also generally better than those for the satellite-derived $a_{\mathrm{ph}}$. Compared with the satellite-derived $a_{\mathrm{ph}}$, the PVP for the satellite-derived $a_{\mathrm{ph}}^{\mathrm{rc}}$ significantly increased with an average of $23.48 \%$. Meanwhile, Fig. 6 also shows that the satellitederived $a_{\mathrm{ph}}^{\mathrm{rc}}$ had more valid samples and were more clustered around the $1: 1$ line than the satellite-derived $a_{\mathrm{ph}}$. Overall, both Table 5 and Fig. 6 indicated that the satellite-derived $a_{\mathrm{ph}}$ had poor accuracy and low PVP values, whereas the accuracy of satellite-derived $a_{\mathrm{ph}}^{\text {rc }}$ can be significantly improved 


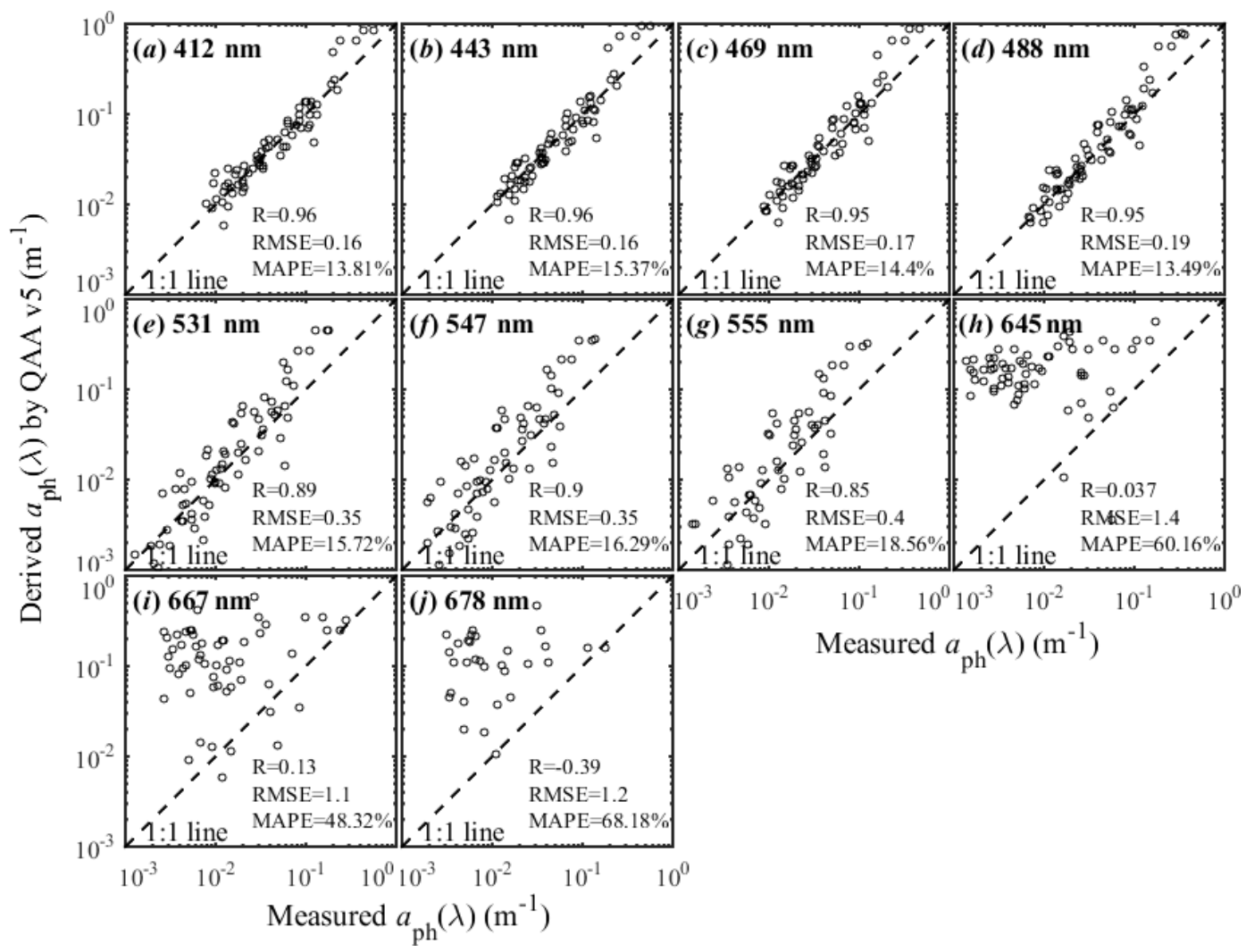

Figure 4. Comparison of $a_{\mathrm{ph}}$ derived from $R_{\mathrm{rs}}$ using QAA_v5 with in situ measured $a_{\mathrm{ph}}$ data.
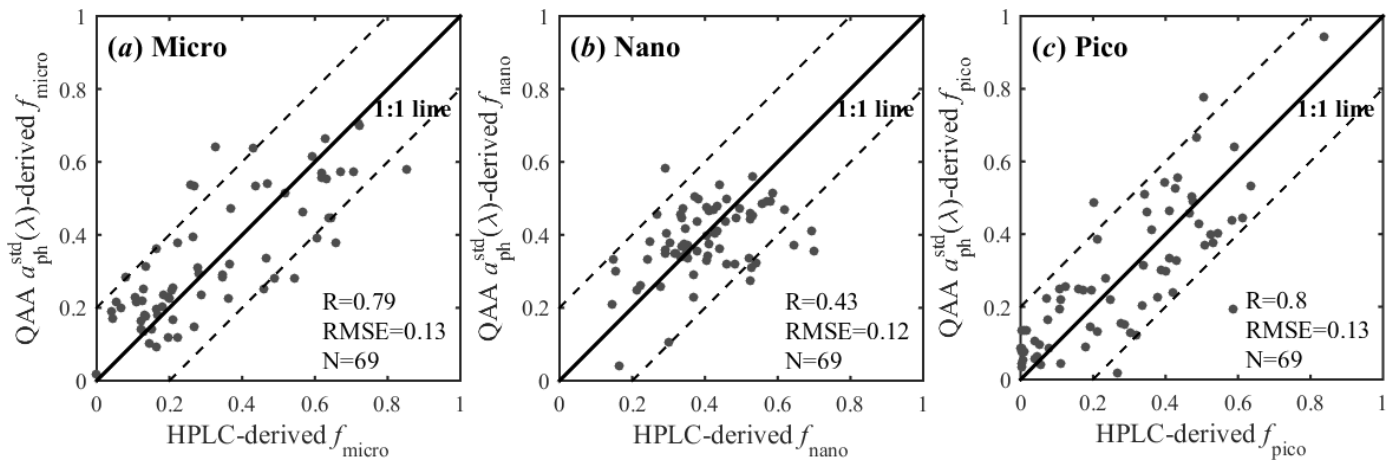

Figure 5. Comparisons of the PSC modeled using $a_{\mathrm{ph}}$ derived from $R_{\mathrm{rs}}$ with the HPLC-derived values for micro- (a), nano- (b), and picophytoplankton (c).

with more valid samples through the reconstruction of satellite $R_{\mathrm{rs}}$ data.

The refined PSC model was applied to the satellite-derived $a_{\mathrm{ph}}$ data from original satellite $R_{\mathrm{rs}}$ to estimate PSC (Fig. 7a). It can be seen that the satellite-derived PSC from original satellite $R_{\mathrm{rs}}$ was inconsistent with the HPLC-derived results, showing obvious underestimations and overestimations of the retrieved PSC for most of the samples. Their $R$ values were all below 0.27 (Fig. 7a). For comparison, we also estimated the PSC from the satellite-derived $a_{\mathrm{ph}}^{\mathrm{rc}}$ from reconstructed $R_{\mathrm{rs}}^{\mathrm{rc}}$ data and compared it with the HPLCderived values (Fig. 7b). The satellite-derived PSC from reconstructed $R_{\mathrm{rs}}^{\mathrm{rc}}$ data agreed well with the HPLC-derived results. Their $R$ values of $0.68,0.46$, and 0.64 and RMSE values of $0.13,0.13$, and 0.19 were observed for micro-, nano-, and pico-phytoplankton, respectively. Almost all of the samples fell within the $\pm 20 \%$ fraction range, although a slight underestimation of pico-phytoplankton size fraction occurred in a few samples. 
Table 2. Results of the matchup comparison of satellite $R_{\mathrm{rs}}(\lambda)$ with in situ measurements.

\begin{tabular}{lrrrrrrrrrr}
\hline & \multicolumn{10}{c}{ Wavelength (nm) } \\
\cline { 2 - 11 } & 412 & 443 & 469 & 488 & 531 & 547 & 555 & 645 & 667 & 678 \\
\hline$N$ & 21 & 21 & 21 & 21 & 21 & 21 & 21 & 21 & 21 & 21 \\
$R$ & 0.46 & 0.73 & 0.85 & 0.88 & 0.95 & 0.96 & 0.97 & 0.90 & 0.86 & 0.85 \\
RMSE & 0.0026 & 0.0019 & 0.0016 & 0.0016 & 0.0011 & 0.0011 & 0.0012 & 0.00081 & 0.00077 & 0.00079 \\
MAPE (\%) & 47.33 & 36.90 & 27.25 & 19.92 & 16.39 & 14.90 & 18.41 & 54.86 & 91.39 & 111.3 \\
\hline
\end{tabular}

Table 3. Statistical parameters and coefficients for the algorithm to reconstruct $R_{\mathrm{rs}}$ data.

\begin{tabular}{|c|c|c|c|c|c|}
\hline Wavelengths & $N$ & $R^{2}$ & RMSE & MAPE & $\begin{array}{r}\text { Constant coefficients } \\
K_{j}, j=0,1, \ldots n \\
\end{array}$ \\
\hline $412 \mathrm{~nm}$ & 341 & 0.99 & $6.3 \times 10^{-4}$ & $8.50 \%$ & $\begin{array}{r}4.43 \times 10^{-4}, 3.91, \\
-3.19,0.20,0.72,-0.69\end{array}$ \\
\hline $443 \mathrm{~nm}$ & 341 & 0.99 & $2.2 \times 10^{-4}$ & $3.13 \%$ & $\begin{array}{r}7.39 \times 10^{-5}, 2.50,-1.59 \\
-0.36,1.22,-0.77\end{array}$ \\
\hline
\end{tabular}

Additionally, to further examine the performance of the refined PSC model in our study, our refined PSC model was compared with another two published PSC models (the Brewin et al., 2015, model and the Sun et al., 2017, model) (Fig. 7c and d). Here, we regionally tuned these published models using a standard nonlinear least-squares method based on our field dataset collected in the ECS. It should be noted here that the two retuned models were used to better assess the performance of our refined PSC model only, although these "abundance-based" models may not perform well in the ECS (data not shown), as suggested by Wang et al. (2014). In this study, the retuned Brewin et al. (2015) model for the ECS was expressed as

$$
\begin{aligned}
& f_{\text {pico }}=0.19[1-\exp (-3.6 \mathrm{Chl} a)] / \mathrm{Chl} a, \\
& f_{\mathrm{p}, \mathrm{n}}=1.0[1-\exp (-1.0 \mathrm{Chl} a)] / \operatorname{Chl} a, \\
& f_{\text {nano }}=f_{\mathrm{p}, \mathrm{n}}-f_{\text {pico }} \text { and } f_{\text {micro }}=1-f_{\mathrm{p}, \mathrm{n}},
\end{aligned}
$$

where $f_{\mathrm{p}, \mathrm{n}}$ is the sum of the nano- and pico-phytoplankton size fraction. And, the retuned Sun et al. (2017) model for the ECS was expressed as

$$
\begin{aligned}
& f_{\text {pico }}=0.66 \mathrm{Chl} a^{-1}\left[1-\exp \left(-\mathrm{Chl} a^{2} \times R_{\mathrm{rs}}(680)\right)\right]^{0.16}, \\
& f_{\text {nano }}=4.17 \mathrm{Chl} a^{-1}\left[1-\exp \left(-\mathrm{Chl} a^{2} \times R_{\mathrm{rs}}(680)\right)\right]^{0.32}, \\
& f_{\text {micro }}=1-f_{\text {nano }}-f_{\text {pico }},
\end{aligned}
$$

where $R_{\mathrm{rs}}(680)$ is the remote sensing reflectance at $680 \mathrm{~nm}$. The scatter distributions of the satellite-derived PSC using our refined PSC model were closer to the $1: 1$ line than those of the other two models. According to the statistical indicators, our refined PSC model had the best performance, with higher $R$ values and lower RMSE values (Fig. 7b). For the retuned Brewin et al. (2015) model, the $R$ values of 0.58 ,
0.066 , and 0.53 and RMSE values of $0.2,0.14$, and 0.18 were observed for micro-, nano-, and pico-phytoplankton, respectively (Fig. 7c). For the retuned Sun et al. (2017) model, the $R$ values were $0.36,-0.042$, and 0.5 for micro-, nano-, and pico-phytoplankton, when the corresponding RMSE values were $0.25,0.17$, and 0.18 , respectively (Fig. $7 d$ ). The retuned Brewin et al. (2015) model and the retuned Sun et al. (2017) model had relatively poor performance in the ECS. These comparison results indicated that the performance of our refined PSC model using the reconstructed satellite data was better than those of the retuned Brewin et al. (2015) model and the retuned Sun et al. (2017) model in our study region.

Overall, these results suggested that the use of satellite $R_{\mathrm{rs}}^{\mathrm{rc}}$ could significantly improve the performance of the refined PSC model on satellite observations and yielded reasonable satellite-derived PSC results, which were better than those derived from original satellite observations. Therefore, we further investigated the spatiotemporal variability of the PSC in the ECS based on satellite-derived products from the reconstructed satellite remote sensing reflectance.

\subsection{Seasonal distribution patterns of the PSC in the ECS}

To describe the seasonal variability of the PSC in the ECS, the refined PSC model was applied to 14 years (2003-2016) of MODIS monthly $R_{\text {rs }}$ data to obtain monthly PSC products. Then, seasonal composite PSC images were generated by averaging the monthly PSC products over a 3-month period for each season (Fig. 8a-1). In this study, spring, summer, autumn, and winter were defined as March to May, June to August, September to November, and December to February of the next year, respectively. Meanwhile, to better understand the spatiotemporal variations of PSC, we analyzed the sea- 
Table 4. Comparison of the original satellite $R_{\mathrm{rs}}$ and reconstructed $R_{\mathrm{rs}}^{\mathrm{rc}}$ with in situ measured data at 412 and $443 \mathrm{~nm}$.

\begin{tabular}{lrrrr|rrr}
\hline \multirow{2}{*}{ wavelength } & \multirow{2}{*}{$N$} & \multicolumn{3}{c|}{ original satellite $R_{\mathrm{rs}}$} & \multicolumn{3}{c}{ reconstructed satellite $R_{\mathrm{rs}}^{\mathrm{rc}}$} \\
\cline { 2 - 8 } & & $R$ & RMSE & MAPE (\%) & $R$ & RMSE & MAPE (\%) \\
\hline \multirow{2}{*}{$412 \mathrm{~nm}$} & 21 & 0.46 & 0.0026 & 47.33 & 0.70 & 0.0019 & 35.15 \\
$443 \mathrm{~nm}$ & 21 & 0.73 & 0.0019 & 36.90 & 0.80 & 0.0017 & 34.53 \\
\hline
\end{tabular}

Table 5. Results of the matchup comparison for Fig. 6.

\begin{tabular}{|c|c|c|c|c|c|c|c|c|c|}
\hline \multirow[t]{2}{*}{ wavelength } & \multirow[t]{2}{*}{$N$} & \multicolumn{4}{|c|}{ satellite-derived $a_{\mathrm{ph}}^{\mathrm{rc}}$} & \multicolumn{4}{|c|}{ satellite-derived $a_{\mathrm{ph}}$} \\
\hline & & $R$ & RMSE & MAPE (\%) & PVP (\%) & $R$ & RMSE & MAPE (\%) & $\operatorname{PVP}(\%)$ \\
\hline $412 \mathrm{~nm}$ & 22 & 0.80 & 0.27 & 15.35 & 100 & 0.58 & 0.56 & 58.15 & 72.73 \\
\hline $443 \mathrm{~nm}$ & 22 & 0.83 & 0.23 & 14.87 & 100 & 0.48 & 0.67 & 63.95 & 72.73 \\
\hline $469 \mathrm{~nm}$ & 22 & 0.85 & 0.21 & 11.62 & 100 & 0.62 & 0.55 & 48.35 & 81.82 \\
\hline $488 \mathrm{~nm}$ & 22 & 0.84 & 0.22 & 11.52 & 100 & 0.78 & 0.37 & 31.93 & 90.91 \\
\hline $531 \mathrm{~nm}$ & 22 & 0.80 & 0.31 & 20.82 & 86.36 & 0.86 & 0.73 & 45.57 & 54.55 \\
\hline $547 \mathrm{~nm}$ & 22 & 0.69 & 0.43 & 20.38 & 90.91 & 0.69 & 0.52 & 35.71 & 63.64 \\
\hline
\end{tabular}

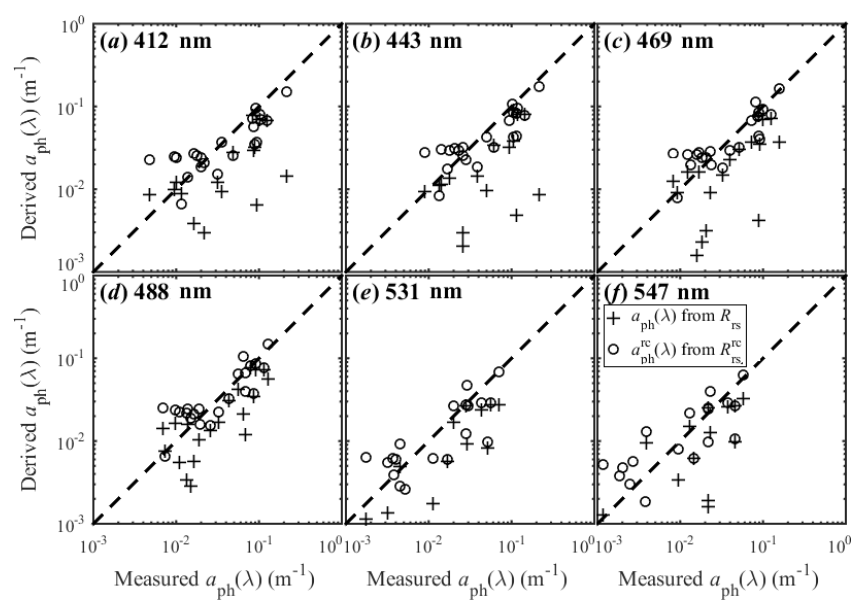

Figure 6. Comparison of the satellite-derived $a_{\mathrm{ph}}$ (crosses) and satellite-derived $a_{\mathrm{ph}}^{\mathrm{rc}}$ (open circles) with in situ measured data at $412,443,469,488,531$, and $547 \mathrm{~nm}$.

sonal distributions of Chl $a$ in the ECS for four seasons, as shown in Fig. 8a-d.

Seasonal distributions of $\mathrm{Chl} a$ (Fig. 8a-d) illustrated that Chl $a$ was higher $\left(0.4-3.0 \mathrm{mg} \mathrm{m}^{-3}\right)$ on the ECS shelf than in the Kuroshio water $\left(<0.4 \mathrm{mg} \mathrm{m}^{-3}\right)$, and the Chl $a$ values in the Changjiang River mouth were particularly high (3.0$\left.25 \mathrm{mg} \mathrm{m}^{-3}\right)$. During spring, the high Chl $a\left(>1.0 \mathrm{mg} \mathrm{m}^{-3}\right)$ was found on the ECS shelf, and the tongue-shaped structure was unclear because of the increase in Chl $a$ in the surrounding areas. During summer, Chl $a$ values above $1.0 \mathrm{mg} \mathrm{m}^{-3}$ were observed in the coastal region. The higher $\mathrm{Chl} a$ $\left(>3.0 \mathrm{mg} \mathrm{m}^{-3}\right)$ was limited to the regions at depths shallower than $30 \mathrm{~m}$ isobath, including the Changjiang mouth. In the autumn, the Chl $a$ remained high in the coastal re- gion $\left(>2.0 \mathrm{mg} \mathrm{m}^{-3}\right)$. The tongue-shaped structure extended outward the southeast along the $50 \mathrm{~m}$ isobath during autumn and along the $70 \mathrm{~m}$ isobath during winter.

Seasonal variation patterns of the PSC (Fig. 8a-1) indicated that the phytoplankton size classes in the ECS were heterogeneous in both temporal and spatial scales. Their general distribution patterns were consistent with results reported from field measurements by other researchers (Chen, 2000; Furuya et al., 2003; Wang et al., 2015). In the spring (Fig. $8 \mathrm{a}-\mathrm{c})$, the higher $f_{\text {micro values }}(0.45-0.85)$ were found on the ECS shelf sea with lower values in offshore waters. Relatively high $f_{\text {nano }}(0.4-0.6)$ were clearly observed on offshore shelf and in southern Japan. However, picophytoplankton were the dominant size class over the southeastern ECS $\left(f_{\text {pico }}=0.50-0.75\right)$. During summer (Fig. $8 \mathrm{~d}-$ f), the micro-phytoplankton size fractions were still high in coastal waters. The high $f_{\text {micro }}$ tongue-shape structure near the Changjiang Bank extended toward southeast along the $30 \mathrm{~m}$ isobath. High nano-phytoplankton proportions occurred in the ECS shelf sea with water depths of 30-200 m. The pico-phytoplankton contributions to Chl $a$ were relatively high around the ECS shelf break. Pico-phytoplankton represented the most abundant size class in the areas deeper than $200 \mathrm{~m}\left(f_{\text {pico }}>0.6\right)$, which was similar to the results from the field measurements by Chen (2000). In the autumn (Fig. $8 \mathrm{~g}-\mathrm{i}$ ), the $f_{\text {micro }}$ remained high in coastal waters and extended over the area shallower than $50 \mathrm{~m}$ isobath. The proportion patterns of nano- and pico-phytoplankton in the autumn were broadly similar to those in the summer. However, high nano-phytoplankton proportions were also in the northern Japan. In the winter (Fig. $8 \mathrm{j}-1$ ), high $f_{\text {micro }}$ were mainly distributed on the ECS shelf. The regions with higher $f_{\text {micro }}$ $(>0.5)$ extended outward, and connected to the area around 
(a) From original $R_{\mathrm{rs}}$ using the refined PSC model

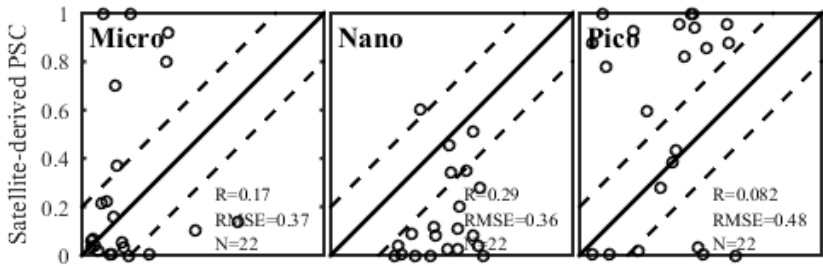

(b) From reconstructed $R_{\mathrm{rs}}^{\mathrm{rc}}$ using the refined PSC model

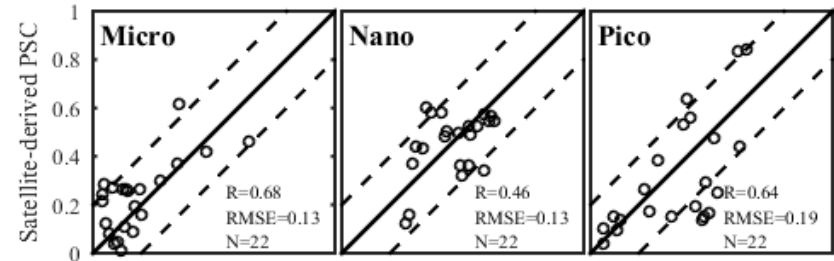

(c) Using the retuned Brewin et al. (2015) model

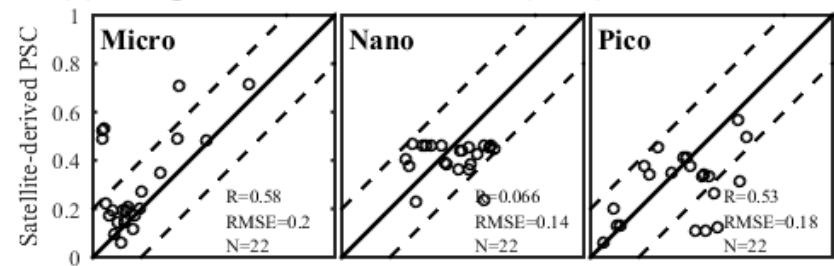

(d) Using the retuned Sun et al. (2017) model

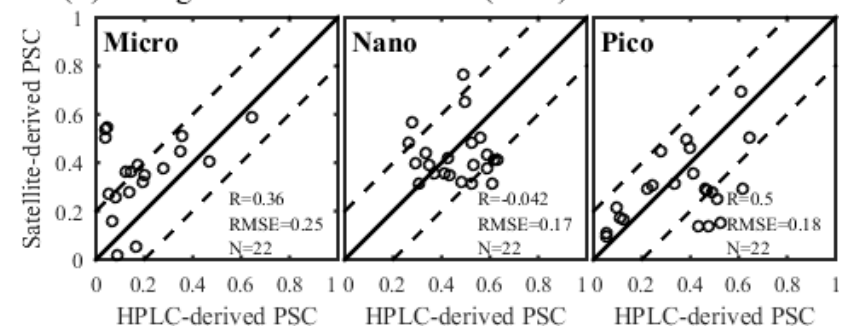

Figure 7. Comparison of the HPLC-derived PSC with the satellitederived PSC values from the original satellite $R_{\mathrm{rs}}(\mathbf{a})$ and the reconstructed satellite $R_{\mathrm{rs}}^{\mathrm{rc}}$ (b) using the refined PSC model in this study; using the retuned Brewin et al. (2015) model (c); using the retuned Sun et al. (2017) model (d). Solid lines denote the $1: 1$ lines.

the Korean coast. The distributions of the size fractions of nano- and pico-phytoplankton were broadly similar to those in the spring.

\subsection{Regional difference in the monthly climatological PSC in the ECS}

Since the East China Sea is extensive, with a number of different environmental conditions and ecosystems, three subareas were selected for further investigation as shown in Fig. 1a. Within each of the subareas, this study investigated averages of the monthly climatological PSC, as well as chlorophyll $a$ concentration (Fig. 9).

In the MCJR, higher Chl $a$ was observed throughout the year $\left(>3.0 \mathrm{mg} \mathrm{m}^{-3}\right)$, and two $\mathrm{Chl} a$ peaks occurred in the spring (May) and summer (June), respectively (Fig. 9a).
Throughout the year, micro-phytoplankton comprised 60 $80 \%$ of the Chl $a$, with the maximum value in April and relatively low fractions from summer to early autumn (JuneSeptember). Nano-phytoplankton comprised $18-30 \%$ of the $\mathrm{Chl} a$, while the contributions of pico-phytoplankton to $\mathrm{Chl} a$ were below $10 \%$ throughout the year (Fig. 9a). In the MSR, mean Chl $a$ in this region domain was lower than that in the MCJR, with a peak in the spring (April) (Fig. 9b). The micro-phytoplankton proportions were slightly larger than pico-phytoplankton in the winter and spring, while the opposite was found in the summer and autumn. The pico-phytoplankton in the MSR were highest in August and September, with a peak in the summer and early autumn (June-September). Nano-phytoplankton were dominant (40-50\%) for most of the year in this region (Fig. 9b). In contrast to the MCJR and MSR, the mean Chl $a$ was much lower in the Kuroshio region throughout the year $\left(<0.3 \mathrm{mg} \mathrm{m}^{-3}\right)$ (Fig. 9c). The KR domain showed a predominance of pico-phytoplankton (40-90\%) throughout the year, with higher proportions observed in the summer. The nanophytoplankton proportions (about $40 \%$ ) were slightly lower than pico-phytoplankton in the winter and early spring, while their proportions became low $(<20 \%)$ in the rest of the year. The micro-phytoplankton size fractions in the KR remained low $(<23 \%)$ throughout the year (Fig. 9c).

\section{Discussion}

\subsection{Satellite application of the refined PSC model}

The most important advantage of satellite ocean color data is the ability to provide information on the spatiotemporal variability of the PSC. However, remote sensing of the PSC in the ECS is still a challenging task, although many "abundancebased" and "spectral-based" algorithms have been designed using field measurements and satellite data in the global scale. Taking into account the optical property in the ECS, Wang et al. (2014) reported that the "abundance-based" approaches are not necessarily applicable in the ECS, and the absorption spectra of phytoplankton could instead be used to obtain the PSC in the ECS. More than $80 \%$ of the variability in the spectral shape of phytoplankton absorption was highly related to the changes in the size classes (Ciotti et al., 2002; Bricaud et al., 2004). Therefore, in this study we refined the Wang et al. (2015) model for deriving PSC in the ECS from the spectral variation of $a_{\mathrm{ph}}$. However, the application of this refined PSC model to original MODIS data has hampered, as showed in Fig. 7a. This may be related to the low accuracy of the MODIS $R_{\mathrm{rs}}$ at 412 and $443 \mathrm{~nm}$ (Table 2), which can introduce additional uncertainties into the satellite-derived $a_{\mathrm{ph}}$ from original $R_{\mathrm{rs}}$ (Fig. 6; Table 5), and thereby affect the estimation accuracy of the satellite-derived PSC (Fig. 7a). To solve this problem, the multivariable linear relationship was employed to reconstruct MODIS $R_{\mathrm{rs}}(412)$ and $R_{\mathrm{rs}}(443)$ val- 

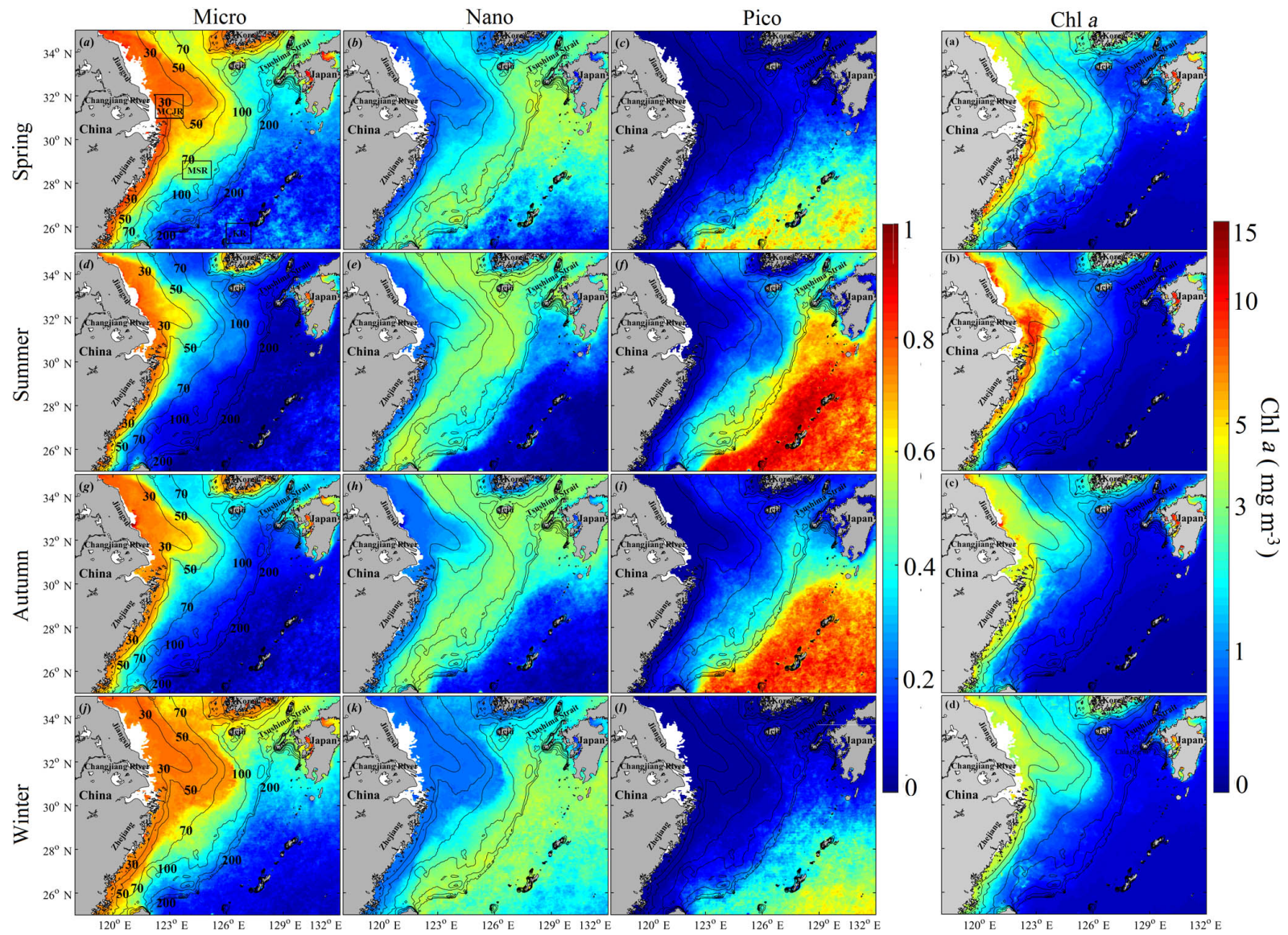

Figure 8. Seasonal distributions of the PSC (a-l) and Chl $a$ (a-d, right panel) in the ECS during 2003-2016.

ues using satellite $R_{\mathrm{rs}}$ from 469 to $555 \mathrm{~nm}$. Previous studies have reported that the use of multiple spectral bands could successfully reconstruct hyperspectral $R_{\mathrm{rs}}$ data (Lee et al., 2014; Sun et al., 2015). In our study, the use of satellite $R_{\mathrm{rs}}^{\mathrm{rc}}$ improved the accuracy and PVP of the satellite-derived $a_{\mathrm{ph}}^{\mathrm{rc}}$ data using QAA_v5 (Fig. 6; Table 5), and dramatically improved the accuracy of the satellite-derived PSC (Fig. 7b). The $R$ and RMSE values for all size fractions derived from the reconstructed satellite $R_{\mathrm{rs}}$ data were 0.7 and 0.15 respectively, compared to the values of 0.064 and 0.38 respectively for those derived from original satellite $R_{\mathrm{rs}}$ data. Overall, this study successfully estimated the PSC in the ECS from the reconstructed MODIS remote sensing reflectance. The findings presented here complement recent studies that have demonstrated that satellite ocean color data can be used to retrieve the PSC in the ECS (Wang et al., 2015; Sun et al., 2017). However, it should be noted that there was no assessment of the credibility of satellite-derived PSC results in the Kuroshio waters due to lack of field dataset in this region, and further investigations focusing on the applicability of the reconstruction algorithm and the refined PSC model in Kuroshio waters and other regions are still required.

\subsection{Spatial and temporal variations of the PSC in the ECS}

As described in the results Sects. 3.5 and 3.6, the seasonal distributions of the PSC and Chl $a$ in the East China Sea (Figs. 8 and 9) had great variability spatially and temporally. In general, micro-phytoplankton are favored under environmental conditions with stronger mixing and high nutrients, while pico-phytoplankton are dominant in low-nutrient waters (IOCCG, 2014; Lamont et al., 2018). Here, we discussed the regional-scale characterization of the full seasonal cycle in stellate-derived PSC and Chl $a$ and the related physical and biochemical effects for helping to understand the spatiotemporal variability of the PSC in the ECS.

\subsubsection{The coastal region}

In the coastal region, such as the coast of Zhejiang and Jiangsu (including the mouth area of the Changjiang River), the combined effects of variable wind forcing, riverine discharge, and vertical mixing of the water column promote phytoplankton growth, resulting in high biomass levels and the presence of larger-sized phytoplankton (Zhou et al., 2008; Wang et al., 2014). Seasonal distributions and vari- 

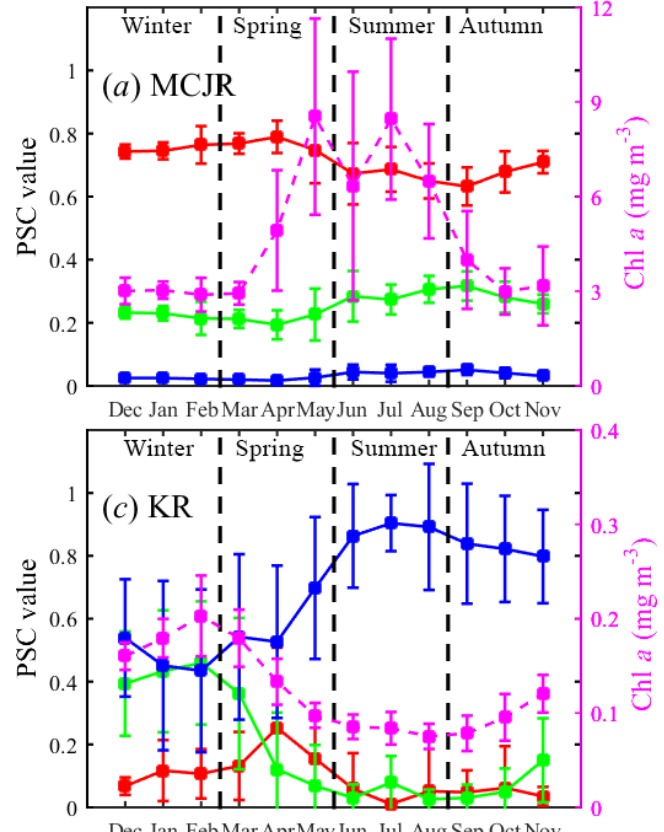

Dec Jan Feb Mar AprMayJun Jul Aug Sep Oct Nov
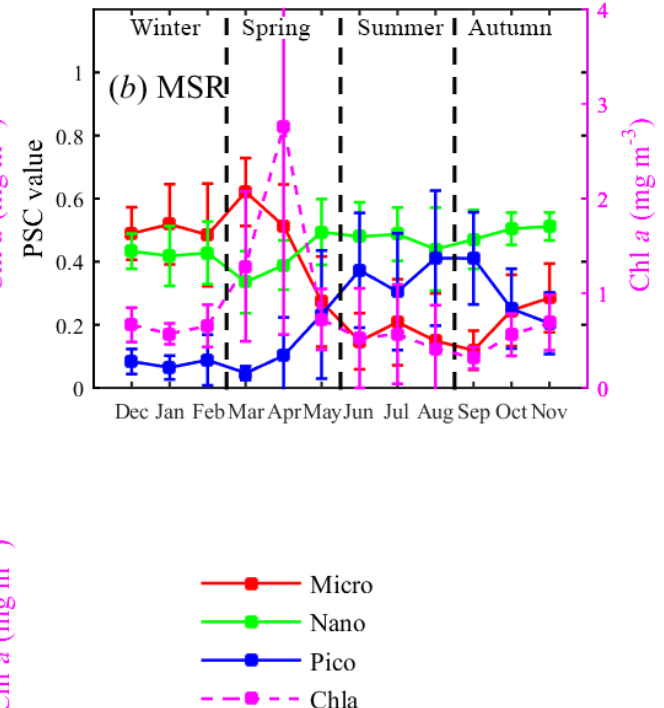

Figure 9. Monthly climatological PSC and Chl $a$ from 2003 to 2016 in the mouth area of the Changjiang River (MCJR) (a), middle shelf region (MSR) (b), and Kuroshio region (KR) (c). Error bars indicate standard deviations of the means.

ability of Chl $a$ (Figs. 8a-d and 9a) in the coastal region presented in this study generally agreed well with the patterns reported by previous studies of satellite $\mathrm{Chl} a$ (Yamaguchi et al., 2012; He et al., 2013).

In the spring, increased solar radiation and air temperature gradually warm up SST, which can reduce the vertical mixing of the water column. At the same time, weak wind stress can retain mixing of the water column, which transports nutrients to the upper layer from the nutrient-rich deep layer (Behrenfeld et al., 2006; Boyce et al., 2010). Meanwhile, coastal nutrient transporting to the inner shelf of the ECS can be enhanced under the northwesterly wind action (Liu and Wang, 2013). These physical processes can allow phytoplankton to live longer in the upper euphotic layer in the sufficient nutrient and light conditions (Zhang et al., 2017), resulting in the spring bloom in the coastal region and inner shelf of the ECS (Fig. 8a), consistent with a previous study by Liu et al. (2016) based on the field measurement of Chl $a$. This phenomenon was also clearly seen in Fig. 9a showing the monthly climatological Chl $a$ in the MCJR with a local maximum in April and May. These enhanced nutrient conditions favor the presence of micro-phytoplankton in the Changjing bank and coastal waters (Figs. 8a and 9a) and nano-phytoplankton in the offshore region (Fig. 8b). This was consistent with previous studies which showed that the large cell sizes, such as diatoms and Prorocentrum donghaiense, were dominant on the ECS shelf sea in the spring (Furuya et al., 2003; Lou and Hu, 2014; Liu et al., 2016).

In the summer, the coastal region with shallower than $40 \mathrm{~m}$ isobath displayed higher Chl $a$ (Fig. 8b) and higher micro- phytoplankton proportion (Fig. 8d). In the mouth area of the Changjiang River, a long-lasting summer Chl $a$ maximum form May to August was found. This may be related to the enhanced nutrient concentrations from river and estuarine discharges, e.g., the Changjiang River, Qiantangjiang River, and Minjiang River (Guo et al., 2014). Due to anthropogenic activities such as various agricultural and industry activities, nutrient-rich waters discharge into the East China Sea, especially in the summer monsoon rainy season (Siswanto et al., 2008). This is especially evident in higher Chl $a$ concentrations and higher micro-phytoplankton proportions observed in the MCJR (Fig. 9a). Meanwhile, the littoral currents, e.g., the Zhe-Min Coastal Current (ZMCC) and Yellow Sea Coastal Current (YSCC), may play a key role in the transport of nutrient from riverine discharge. Previous studies reported that much of sediments is transported southward along the Zhejiang-Fujian coast by the ZMCC (Liu et al., 2007). In addition, the coastal region is relatively shallow, and the water body therefore has a weak stratification of water column in the summer. The hydrodynamic in coastal waters is dominated by the variation of wind-tidethermohaline circulations (Guan, 1994). These physical conditions may lead to the increase in nutrient and thereby influence the phytoplankton size structure in the coastal region. Nano-phytoplankton were found to dominate the inner part of the ECS shelf (Fig. 8e), likely due to the increased nutrient concentrations in offshore waters resulting from the coastal region by strong convection currents. The study of Yamaguchi et al. (2012) revealed that the CDW takes approximately 2 months to move from the Changjiang River 

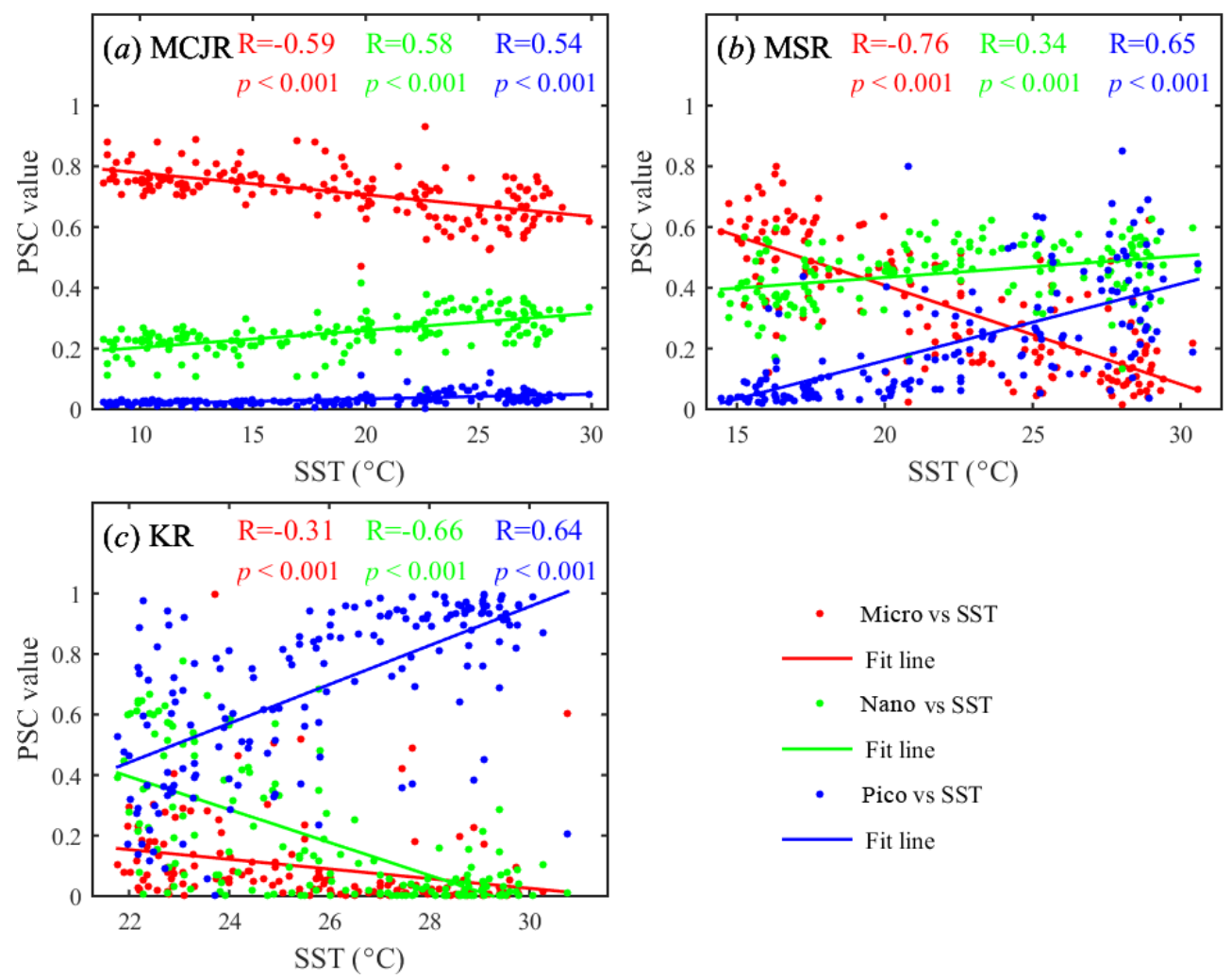

Figure 10. The scatterplots showing the relationships between the monthly phytoplankton size fractions and SST from 2003 to 2016 for the MCJR (a), MSR (b), and KR (c).

mouth to the Tsushima Strait. Therefore, the nutrient supply from riverine discharge may be a major controlling factor in the large cell sizes (micro- and nano-phytoplankton) in the coastal region in the summer. These findings were consistent with the study of Jiang et al. (2015) based on field investigations who reported that the micro-sized diatoms and dinoflagellates dominated the Changjiang estuary and adjacent areas in the summer in response to available nutrients.

During autumn and winter, as wind stress strengthens and temperature decreases, convectional mixing of the water column increases and the stratification weakens, which bring nutrients upward from the underlying layer. The mixing processes through internal waves, tides, and winds, as well as the terrestrial nitrate from runoff, provide a high nutrient condition, which promotes the phytoplankton growth and the presence of larger-sized phytoplankton, as suggested by Taylor and Joint (1990). Guo et al. (2014) also observed that the nitrate concentrations were high in coastal waters of the ECS during autumn and winter. Thus, the larger-sized phytoplankton (micro and nano) dominance was clearly observed in the coastal region (Fig. 8g-h and j-k), and high Chl $a$ was found in this region (Fig. 8c and d), consistent with previous studies by Guo et al. (2014) and Wang et al. (2014), who suggested that the most dominant phytoplankton groups were chain-forming diatoms and dinoflagellates in coastal waters throughout the year.

\subsubsection{The middle shelf and shelf break of the ECS}

Similar to the coastal region, the middle shelf of the ECS exhibited the spring bloom with a peak of Chl $a$ occurring in April, and micro-phytoplankton dominance (Fig. 9b), mainly due to mixing processes of the water column in the spring. These results agree with a previous study reported by Liu et al. (2016) that during springtime, the contributions of dinoflagellates and diatoms (micro) to total $\mathrm{Chl} a$ were relatively higher in the middle shelf region and particularly in the river plume. During summer and early autumn, due to surface warming and low wind stress, the reduced mixing and stronger thermal stratification result in less nutrient supply to the surface layers. As reported by Guo et al. (2014), a nitracline formed in the middle shelf water in summer, and no nitracline formed in autumn and winter due to strong water mixing. This region is also affected by ocean currents carrying warm waters, e.g., the Kuroshio Branch Current to the north of Taiwan and the Yellow Sea Coastal Current (Ichikawa and Beardsley, 2002), which can enhance the water column stability. These oligotrophic conditions can favor the presence of pico-phytoplankton. Meanwhile, the coastal nutrients are transported to the middle 
shelf region by convection currents, but the nutrient concentrations in the middle shelf are not as high as those in the coastal region. This may be one reason that nano- and picophytoplankton size classes overlapped during summer and early autumn (Figs. 8e-f and 9b). In the winter, mixing of the water column increases due to strong winds (Guo et al., 2014), allowing nutrients to enter the surface layer. This condition favors the increase in micro- and nano-phytoplankton in the middle shelf of the ECS (Fig. 9b). Previous studies have shown that micro-phytoplankton dominated the shelf regions in wind-driven upwelling and mixing systems, where nutrient concentrations are high and seawater temperatures are lower (Hirata et al., 2009; Sun et al., 2017; Lamont et al., 2018). These larger-sized phytoplankton-dominated communities can support higher rates of photosynthesis because of their larger photosynthetic rates per unit volume (Hirata et al., 2009). Additionally, upwelling usually occurs at the shelf break of the ECS, transposing nutrient-rich waters from the subsurface layer to the upper layer (Chen et al., 2009). This condition can promote the nano-phytoplankton growth. Advective processes in the upwelling system are regarded as an important force, as well as the biochemical forces such as nutrients, in controlling the phytoplankton size structure and species composition (Smith et al., 1983). Malone (1975) reported that small nano-phytoplankton were selectively removed from upwelling regions by mass transport to the distance as a result of their low sinking rates.

\subsubsection{The Kuroshio region and open ocean}

In comparison to the ECS shelf sea, the Kuroshio region and open ocean generally exhibited relatively low chlorophyll $a$ concentrations (Figs. 8a-d and 9c). These phytoplankton biomass levels are controlled by a variety of forcing factors, among which the key factors are water column stability and the availability of light and nutrients (Behrenfeld, 2010; Yamaguchi et al., 2012). The Kuroshio region is largely influenced by the Kuroshio, in addition to solar irradiance that governs light availability and also influences the water column stability. The mainstream of the Kuroshio strongly flows northeastward along around the $200 \mathrm{~m}$ isobath (Ichikawa and Beardsley, 2002), carrying warm and lownutrient waters (Jiao et al., 2005). High surface temperature could strengthen the water column stability, thereby preventing the nutrient supply to the upper layer from the deeper layer (Lovelock, 2007). Thus, these oligotrophic conditions lead to the low phytoplankton biomass and promote the growth of pico-phytoplankton, which are better adapted to take advantage of such light and nutrient-depleted conditions (Finkel et al., 2009). Liu et al. (2016) found that the importance of larger phytoplankton (diatoms and dinoflagellates) decreased appreciably in the offshore waters, and their contributions were partially replaced by small-sized phytoplankton (e.g., Synechococcus, Prochlorococcus, chrysophytes, and prymnesiophytes). On the other hand, this was also con- firmed by a significant positive correlation between SST and pico-phytoplankton proportions in the KR (Fig. 10c). In addition, temperature and salinity are implicated as important ecological determinants for some small-sized photosynthetic bacteria, e.g., Prochlorococcus and Synechococcus. Prochlorococcus are largely confined to the warm waters and almost absent in coastal waters in the winter (Jiao et al., 2005). Some previous studies also showed that for the abundant Prochlorococcus in surface waters, its lower boundaries of temperature and salinity were 15.6 and $33.5^{\circ} \mathrm{C}$ in the winter, respectively, and 26.4 and $29.1^{\circ} \mathrm{C}$ in the summer, respectively (Jiao et al., 2005; Liu et al., 2016). This is particularly clear in the Kuroshio region where pico-phytoplankton were dominant throughout the year, except in winter and early spring when nano-phytoplankton size fractions were slightly more elevated (Fig. 8b and k; Fig. 9c). The slight increase in nano-phytoplankton proportions during winter and early spring may be related to the increased nutrient concentrations that result from vertical mixing due to stronger wind stress during this period, as reported by Liu et al. (2016) that mean surface concentrations of nutrients $\left(\mathrm{NO}_{3}^{-}+\mathrm{NO}_{2}^{-}\right)$in the offshore Kuroshio region were higher in the winter than in the summer, and the mixed-layer depth was much deeper in the winter than in the summer due to strong vertical mixing in the winter.

\subsection{Response of phytoplankton size class to sea surface temperature}

It has previously been suggested that sea surface temperature is one of the important factors that influence the PSC dynamic (Chen, 2000; Barnes et al., 2010; IOCCG, 2014). Based on the 14-year (2003-2016) time series of the monthly SST and satellite-derived PSC data, we investigated the correlations between SST and PSC in the three subareas of the ECS (Fig. 10), aiming to discuss the PSC response to the SST change under different hydrological conditions. In the Kuroshio region, significant negative correlation between nano-phytoplankton size fraction and SST was found ( $R=-0.66<-0.5$ and $p<0.001)$, and weak negative correlation was found for micro-phytoplankton $(R=-0.31)$. Significant positive correlation between pico-phytoplankton size fraction and SST was identified $(R=0.64>0.5$ and $p<0.001$ ) (Fig. 10c). Similarly, Chen (2000) reported that there was a significant positive correlation between in situ measured pico-phytoplankton proportion and water temperature. Several studies have found that surface warming can weaken vertical mixing due to the increase in water column stability (Behrenfeld et al., 2006; Boyce et al., 2010), which causes less nutrient supply to the surface layers from the underlying nutrient-rich waters. In addition, the Kuroshio water is characterized by high salinity, high temperature, and low nutrients (Jiao et al., 2005). These oligotrophic conditions favor the presence of smaller-sized phytoplankton (pico) and restrict the growth of larger-sized phy- 
toplankton (micro and nano). It offers an explanation to help us understand the correlation between the increasing trend of SST and decreasing trend of micro- and nanophytoplankton size fraction and increasing trend of picophytoplankton size fraction. Similar to the KR, a negative correlation between micro-phytoplankton proportion and SST $(R=-0.76$ and $p<0.001)$ and a positive correlation for pico-phytoplankton $(R=0.65$ and $p<0.001)$ were observed in the MSR (Fig. 10b). Different environmental conditions in the two subareas showed similar responses of the variability of micro- and pico-phytoplankton size fractions to SST. However, the increasing trend of SST and increasing trend of nano-phytoplankton showed a weak positive correlation ( $R=0.34$ and $p<0.001)$ (Fig. 10b), which was different to the Kuroshio region. The weak correlation suggested that nano-phytoplankton in this region may be affected by other factors (e.g., grazing-nitrogen rate) other than SST (Furuya et al., 2003). For instance, Barlow et al. (2016) reported that nano-phytoplankton (e.g., flagellates) were dominant in warmer shelf regions, because they are better at utilizing the increase in nutrient concentrations after upwelled water has warmed. In the mouth area of the Changjiang River, the SSTs were negatively $(R=-0.59$ and $p<0.001)$, positively $(R=0.58$ and $p<0.001)$, and positively $(R=$ 0.54 and $p<0.001)$ correlated with micro-, nano-, and picophytoplankton size fraction, respectively (Fig. 10a). The water body in the coastal region mixes well in winter with low SST and has a weak stratification of water column in summer with high SST, as the hydrodynamic in coastal water is dominated by the variation of wind-tide-thermohaline circulations (Guan, 1994). In some degree, increasing SST could result in a decrease in larger-sized phytoplankton (micro and nano) and an increase in small-sized phytoplankton (pico). However, the trend of rising SST and the increasing nanophytoplankton size fraction in the MCJR were observed. This may be related to the optimum temperature for the growth of different algal groups. Additionally, previous studies have shown that the nutrient structure in the ECS was altered by the Changjiang discharge, especially for the Changjiang estuary and adjacent area (Zhang et al., 2007; Wang et al., 2014). The change in nutrient structure (increase in the $N / P$ ratio) may play an important role in regulating the phytoplankton community structure in the MCJR (Guo et al., 2014). These results suggested the interannual variability of PSC in coastal waters is more complicated than in offshore waters. The detailed study focusing on the mechanism of the PCS change in the ECS is still required.

Overall, the correlations between PSC and SST (Fig. 10) indicated SST is an important factor influencing the PSC dynamic in the ECS. The interannual variations of phytoplankton size classes in the ECS were complicated and could not be fully explained by the individual factor. Further investigations therefore are required to understand the interannual variability of the PSC in the ECS and its response to envi- ronmental factors, e.g., wind speed, riverine discharge, and monsoon forcing.

\section{Conclusions}

In this study, the PSC model was regionally tuned for application to the ECS using extensive in situ measured data covering various seasons and environmental conditions in the ECS. When the refined model was applied to MODIS observations, there was a critical step to reconstruct satellite remote sensing reflectance at blue wavebands. It led to reliable performance of the refined PSC model on MODIS observation, which showed good agreement with the HPLCderived PSC results, with almost all of the samples falling within the $\pm 20 \%$ fraction range. Along the way, our present study preliminarily estimated spatial distributions of the PSC in the ECS from space. The refined PSC model was applied to satellite data from MODIS during 2003 and 2016 to investigate the PSC distribution at the seasonal scale. The obtained results showed that the PSC in the ECS varied across both spatial and temporal scales. The seasonality of the PSC in the ECS was likely to be related to the vertical structure of the water column, upwelling, sea surface temperature, and the Kuroshio. It was also affected by riverine discharge and human activity, especially for coastal waters. The interannual and longer-term variations in phytoplankton size class in the East China Sea and their mechanisms need to be investigated in the future.

Data availability. The phytoplankton absorption and size class data are available upon request to the lead author.

Author contributions. HLZ analyzed the data and wrote the manuscript; SQW and ZFQ contributed to the design of this study and interpretation of the results; DYS and JI revised the draft; SJS and YJH provided comments and suggestions to improve the manuscript.

Competing interests. The authors declare that they have no conflict of interest.

Acknowledgements. This research was jointly supported by the National Key Research and Development Program of China (2016YFC1400904), the National Natural Science Foundation of China (41506200, 41576172, and 41276186), the Natural Science Foundation of the Jiangsu Higher Education Institutions of China (15KJB170015), the Provincial Natural Science Foundation of Jiangsu in China (BK20150914, BK20151526, and BK20161532), the National Program on Global Change and Air-sea Interaction (GASI-03-03-01-01), the Public Science and Technology Research Funds Projects of Ocean (201005030), a project funded by "the Priority Academic Program Development of Jiangsu Higher Edu- 
cation Institutions (PAPD)", the Research and Innovation Project for College Graduates of Jiangsu Province (KYLX16_0952), and the China Scholarship Council.

Edited by: Anja Rammig

Reviewed by: two anonymous referees

\section{References}

Aiken, J., Pradhan, Y., Barlow, R., Lavender, S., Poulton, A., Holligan, P., and Hardman-Mountford, N.: Phytoplankton pigments and functional types in the Atlantic Ocean: A decadal assessment, 1995-2005, Deep-Sea Res. Pt. II, 56, 899-917, https://doi.org/10.1016/j.dsr2.2008.09.017, 2009.

Barlow, R., Gibberd, M., Lamont, T., Aiken, J., and Holligan, P.: Chemotaxonomic phytoplankton patterns on the eastern boundary of the Atlantic Ocean, Deep-Sea Res. Pt. I, 111, 73-78, https://doi.org/10.1016/j.dsr.2016.02.011, 2016.

Barnes, C., Irigoien, X., De Oliveira, J. A., Maxwell, D., and Jennings, S.: Predicting marine phytoplankton community size structure from empirical relationships with remotely sensed variables, J. Plankton Res., 33, 13-24, https://doi.org/10.1093/plankt/fbq088, 2010.

Behrenfeld, M. J., O’Malley, R. T., Siegel, D. A., McClain, C. R., Sarmiento, J. L., Feldman, G. C., Milligan, A. J., Falkowski, P. G., Letelier, R. M., and Boss, E. S.: Climate-driven trends in contemporary ocean productivity, Nature, 444, 752-755, https://doi.org/10.1038/nature05317, 2006.

Behrenfeld, M. J.: Abandoning Sverdrup's critical depth hypothesis on phytoplankton blooms, Ecology, 91, 977-989, https://doi.org/10.1890/09-1207.1, 2010.

Bouman, H., Platt, T., Sathyendranath, S., and Stuart, V.: Dependence of light-saturated photosynthesis on temperature and community structure, Deep-Sea Res. Pt. I, 52, 1284-1299, https://doi.org/10.1016/j.dsr.2005.01.008, 2005.

Boyce, D. G., Lewis, M. R., and Worm, B.: Global phytoplankton decline over the past century, Nature, 466, 591-596, https://doi.org/10.1038/nature09268, 2010.

Bracher, A., Bouman, H. A., Brewin, R. J., Bricaud, A., Brotas, V., Ciotti, A. M., Clementson, L., Devred, E., Di Cicco, A., and Dutkiewicz, S.: Obtaining phytoplankton diversity from ocean color: a scientific roadmap for future development, Front. Mar. Sci., 4, 55, https://doi.org/10.3389/fmars.2017.00055, 2017.

Brewin, R. J., Sathyendranath, S., Hirata, T., Lavender, S. J., Barciela, R. M., and Hardman-Mountford, N. J.: A three-component model of phytoplankton size class for the Atlantic Ocean, Ecol. Model., 221, 1472-1483, https://doi.org/10.1016/j.ecolmodel.2010.02.014, 2010.

Brewin, R. J. W., Sathyendranath, S., Jackson, T., Barlow, R., Brotas, V., Airs, R., and Lamont, T.: Influence of light in the mixedlayer on the parameters of a three-component model of phytoplankton size class, Remote Sens. Environ., 168, 437-450, https://doi.org/10.1016/j.rse.2015.07.004, 2015.

Bricaud, A., Claustre, H., Ras, J., and Oubelkheir, K.: Natural variability of phytoplanktonic absorption in oceanic waters: Influence of the size structure of algal populations, J. Geophys. Res.Oceans, 109, 45-50, https://doi.org/10.1029/2004JC002419, 2004.
Chen, C., Gong, G., and Jan, S.: Seasonal and episodic effects (dust storm) on nutrient dynamics in the upwelling across shelf break on the East China Sea to the Kuroshio Water, northeastern Taiwan, AGU Spring Meeting, 24-27 May 2009, 2009.

Chen, Y. L. L.: Comparisons of primary productivity and phytoplankton size structure in the marginal regions of southern East China Sea, Cont. Shelf Res., 20, 437-458, https://doi.org/10.1016/S0278-4343(99)00080-1, 2000.

Ciotti, A. M., Lewis, M. R., and Cullen, J. J.: Assessment of the relationships between dominant cell size in natural phytoplankton communities and the spectral shape of the absorption coefficient, Limnol. Oceanogr., 47, 404-417, https://doi.org/10.4319/lo.2002.47.2.0404, 2002.

Cleveland, J. and Weidemann, A. D.: Quantifying absorption by aquatic particles: A multiple scattering correction for glass-filters, Limnol. Oceanogr., 38, 1321-1327, https://doi.org/10.4319/lo.1993.38.6.1321, 1993.

Finkel, Z. V., Beardall, J., Flynn, K. J., Quigg, A., Rees, T. A. V., and Raven, J. A.: Phytoplankton in a changing world: cell size and elemental stoichiometry, J. Plankt. Res., 32, 119-137, https://doi.org/10.1093/plankt/fbp098, 2009.

Furuya, K., Kurita, K., and Odate, T.: Distribution of phytoplankton in the East China Sea in the winter of 1993, J. Oceanogr., 52, 323-333, https://doi.org/10.1007/BF02235927, 1996.

Furuya, K., Hayashi, M., Yabushita, Y., and Ishikawa, A.: Phytoplankton dynamics in the East China Sea in spring and summer as revealed by HPLC-derived pigment signatures, DeepSea Res. Pt. II, 50, 367-387, https://doi.org/10.1016/S09670645(02)00460-5, 2003.

Guan, B.: Patterns and structures of the currents in Bohai, Huanghai and East China Seas, in: Oceanology of China seas, Springer, Dordrecht, the Netherlands, 17-26, 1994.

Guidi, L., Stemmann, L., Jackson, G. A., Ibanez, F., Claustre, H., Legendre, L., Picheral, M., and Gorskya, G.: Effects of phytoplankton community on production, size, and export of large aggregates: A world-ocean analysis, Limnol. Oceanogr., 54, 19511963, https://doi.org/10.4319/lo.2009.54.6.1951, 2009.

Guo, S., Feng, Y., Wang, L., Dai, M., Liu, Z., Bai, Y., and Sun, J.: Seasonal variation in the phytoplankton community of a continental-shelf sea: the East China Sea, Mar. Ecol. Prog. Ser., 516, 103-126, https://doi.org/10.3354/meps10952, 2014.

He, X., Bai, Y., Pan, D., Chen, C.-T. A., Cheng, Q., Wang, D., and Gong, F.: Satellite views of the seasonal and interannual variability of phytoplankton blooms in the eastern China seas over the past 14 yr (1998-2011), Biogeosciences, 10, 4721-4739, https://doi.org/10.5194/bg-10-4721-2013, 2013.

Hirata, T., Aiken, J., Hardman-Mountford, N., Smyth, T. J., and Barlow, R. G.: An absorption model to determine phytoplankton size classes from satellite ocean colour, Remote Sens. Environ., 112, 3153-3159, https://doi.org/10.1016/j.rse.2008.03.011, 2008.

Hirata, T., Hardman-Mountford, N. J., Barlow, R., Lamont, T., Brewin, R., Smyth, T., and Aiken, J.: An inherent optical property approach to the estimation of size-specific photosynthetic rates in eastern boundary upwelling zones from satellite ocean colour: an initial assessment, Prog. Oceanogr., 83, 393-397, https://doi.org/10.1016/j.pocean.2009.07.019, 2009.

Hirata, T., Hardman-Mountford, N. J., Brewin, R. J. W., Aiken, J., Barlow, R., Suzuki, K., Isada, T., Howell, E., Hashioka, T., Noguchi-Aita, M., and Yamanaka, Y.: Synoptic relationships be- 
tween surface Chlorophyll $a$ and diagnostic pigments specific to phytoplankton functional types, Biogeosciences, 8, 311-327, https://doi.org/10.5194/bg-8-311-2011, 2011.

Hirawake, T., Takao, S., Horimoto, N., Ishimaru, T., Yamaguchi, Y., and Fukuchi, M.: A phytoplankton absorption-based primary productivity model for remote sensing in the Southern Ocean, Polar Biol., 34, 291-302, https://doi.org/10.1007/s00300-0100949-y, 2011.

Hosmer Jr, D. W., Lemeshow, S., and Sturdivant, R. X.: Applied logistic regression, John Wiley \& Sons, Hoboken, New Jersey, 2013

$\mathrm{Hu}, \mathrm{C}$., Feng, L., and Lee, Z.: Uncertainties of SeaWiFS and MODIS remote sensing reflectance: Implications from clear water measurements, Remote Sens. Environ., 133, 168-182, https://doi.org/10.1016/j.rse.2013.02.012, 2013.

Ichikawa, H. and Beardsley, R. C.: The current system in the Yellow and East China Seas, J. Oceanogr., 58, 77-92, https://doi.org/10.1023/A:1015876701363, 2002.

IOCCG: Phytoplankton functional types from Space, in: Reports of International Ocean-Colour Coordinating Group, edited by: Sathyendranath, S., no 15, 1-156, Dartmouth, Canada: IOCCG, 2014.

Jiang, Z., Liu, J., Chen, J., Chen, Q., Yan, X., Xuan, J., and Zeng, J.: Responses of summer phytoplankton community to drastic environmental changes in the Changjiang (Yangtze River) estuary during the past 50 years, Water Res., 54, 1-11, https://doi.org/10.1016/j.watres.2014.01.032, 2014.

Jiang, Z., Chen, J., Zhou, F., Shou, L., Chen, Q., Tao, B., Yan, X., and Wang, K.: Controlling factors of summer phytoplankton community in the Changjiang (Yangtze River) Estuary and adjacent East China Sea shelf, Cont. Shelf Res., 101, 71-84, https://doi.org/10.1016/j.csr.2015.04.009, 2015.

Jiao, N., Yang, Y., Hong, N., Ma, Y., Harada, S., Koshikawa, H., and Watanabe, M.: Dynamics of autotrophic picoplankton and heterotrophic bacteria in the East China Sea, Cont. Shelf Res., 25, 1265-1279, https://doi.org/10.1016/j.csr.2005.01.002, 2005.

Kiørboe, T.: Turbulence, phytoplankton cell size, and the structure of pelagic food webs, Adv. Mar. Biol., 29, 1-72, https://doi.org/10.1016/S0065-2881(08)60129-7, 1993.

Lamont, T., Brewin, R., and Barlow, R.: Seasonal variation in remotely-sensed phytoplankton size structure around southern Africa, Remote Sens. Environ., 204, 617-631, https://doi.org/10.1016/j.rse.2017.09.038, 2018.

Lee, Z., Carder, K. L., and Arnone, R. A.: Deriving inherent optical properties from water color: a multiband quasi-analytical algorithm for optically deep waters, Appl. Opt., 41, 5755-5772, https://doi.org/10.1364/AO.41.005755, 2002.

Lee, Z., Lubac, B., Werdell, J., and Arnone, R.: An update of the quasi-analytical algorithm (QAA_v5), International Ocean Color Group Software Report, 1-9, 2009.

Lee, Z., Shang, S., Hu, C., and Zibordi, G.: Spectral interdependence of remote-sensing reflectance and its implications on the design of ocean color satellite sensors, Appl. Opt., 53, 33013310, https://doi.org/10.1364/AO.53.003301, 2014.

Li, Y., Li, D. J., Tang, J. L., Wang, Y. M., Liu, Z. G., Ding, P. X., and He, S. Q.: Phytoplankton Distribution and Variation in the Yangtze River Estuary and Its Adjacent Sea, Environ. Sci., 28, 719-729, 2007 (in Chinese).
Liu, D. and Wang, Y.: Trends of satellite derived chlorophyll $a$ (1997-2011) in the Bohai and Yellow Seas, China: Effects of bathymetry on seasonal and interannual patterns, Prog. Oceanogr., 116, 154-166, https://doi.org/10.1016/j.pocean.2013.07.003, 2013.

Liu, J., Xu, K., Li, A. E. A., Milliman, J., Velozzi, D., Xiao, S., and Yang, Z.: Flux and fate of Yangtze River sediment delivered to the East China Sea, Geomorphology, 85, 208-224, https://doi.org/10.1016/j.geomorph.2006.03.023, 2007.

Liu, X., Xiao, W., Landry, M. R., Chiang, K. P., Wang, L., and Huang, B.: Responses of Phytoplankton Communities to Environmental Variability in the East China Sea, Ecosystems, 19, 832-849, https://doi.org/10.1007/s10021-016-9970-5, 2016.

Lou, X. and Hu, C.: Diurnal changes of a harmful algal bloom in the East China Sea: Observations from GOCI, Remote Sens. Environ., 140, 562-572, https://doi.org/10.1016/j.rse.2013.09.031, 2014.

Lovelock, J.: The revenge of gaia: Earth's climate crisis \& the fate of humanity, Basic Books, New York, 2007.

Luan, Q. S., Sun, J., Song, S. Q., Shen, Z. L., and Yu, Z. M.: Canonical correspondence analysis of summer phytoplankton community and its environment in the Yangtze River Estuary, China, J. Plant Ecol., 31, 445-450, https://doi.org/10.17521/cjpe.2007.0054, 2007 (in Chinese).

Malone, T. C.: Environmental control of phytoplankton cell size, Limnol. Oceanogr., 20, 490-490, https://doi.org/10.4319/lo.1973.18.4.0511, 1975.

Meister, G.: Calibration and characterization adjustments to the MODIS ocean color band by the OBPG, Proc. MODIS Sci. Team Meeting, 18-20 May 2011, 1-23, 2011.

Mitchell, B. G.: Algorithms for determining the absorption coefficient for aquatic particulates using the quantitative filter technique, Orlando'90, 16-20 April, 137-148, 1990.

Montagnes, D. J., Berges, J. A., Harrison, P. J., and Taylor, F.: Estimating carbon, nitrogen, protein, and chlorophyll a from volume in marine phytoplankton, Limnol. Oceanogr., 39, 1044-1060, https://doi.org/10.4319/lo.1994.39.5.1044, 1994.

Mueller, J. L., Fargion, G. S., Mcclain, C. R., Pegau, S., Zanefeld, J. R. V., Mitchell, B. G., Kahru, M., Wieland, J., and Stramska, M.: Ocean Optics Protocols for Satellite Ocean Color Sensor Validation, Revision 4, Volume IV: Inherent Optical Properties: Instruments, Characterizations, Field Measurements and Data Analysis Protocols, 2003.

Sheldon, R. and Parsons, T. R.: A practical manual on the use of the Coulter Counter in marine research, Coulter Electronics Sales, 1967.

Sieburth, J. M., Smetacek, V., and Lenz, J.: Pelagic ecosystem structure: heterotrophic compartments of the plankton and their relationship to plankton size fractions, Limnol. Oceanogr., 23, 12561263, https://doi.org/10.4319/lo.1978.23.6.1256, 1978.

Siswanto, E., Nakata, H., Matsuoka, Y., Tanaka, K., Kiyomoto, Y., Okamura, K., Zhu, J., and Ishizaka, J.: The long-term freshening and nutrient increases in summer surface water in the northern East China Sea in relation to Changjiang discharge variation, J. Geophys. Res.-Oceans, 113, 2601-2613, https://doi.org/10.1029/2008JC004812, 2008.

Smith, W. O., Heburn, G. W., Barber, R. T., and O'Brien, J. J.: Regulation of phytoplankton communities by physical pro- 
cesses in upwelling ecosystems, J. Mar. Res., 41, 539-556, https://doi.org/10.1357/002224083788519777, 1983.

$\mathrm{Su}$, J. L. and Yuan, Y. L.: Coastal Hydrology in China, Ocean Press, Beijing, 2005 (in Chinese).

Sun, D., Hu, C., Qiu, Z., and Wang, S.: Reconstruction of hyperspectral reflectance for optically complex turbid inland lakes: test of a new scheme and implications for inversion algorithms, Opt. Exp., 23, A718-A740, https://doi.org/10.1364/OE.23.00A718, 2015.

Sun, D., Huan, Y., Qiu, Z., Hu, C., Wang, S., and He, Y.: Remote-Sensing Estimation of Phytoplankton Size Classes From GOCI Satellite Measurements in Bohai Sea and Yellow Sea, J. Geophys. Res.-Oceans, 122, 8309-8325, https://doi.org/10.1002/2017JC013099, 2017.

Sun, S., Lu, J., and Zhang, L.: Applications of flow cytometer in ecological studies of nano- and pico-phytoplankton, Chinese Journal of Ecology, 19, 72-78, 2000 (in Chinese).

Tang, J., Tian, G., Wang, X., Wang, X., and Song, Q.: The methods of water spectra measurement and analysis I: above-water method, J. Remote Sens., 8, 37-44, 2004.

Tassan, S. and Ferrari, G. M.: An alternative approach to absorption measurements of aquatic particles retained on filters, Limnol. Oceanogr., 40, 1358-1368, https://doi.org/10.4319/lo.1995.40.8.1358, 1995.

Tassan, S. and Ferrari, G.: A sensitivity analysis of the "Transmittance-Reflectance" method for measuring light absorption by aquatic particles, J. Plankt. Res., 24, 757-774, https://doi.org/10.1093/plankt/24.8.757, 2002.

Taylor, A. H. and Joint, I.: A steady-state analysis of the "microbial loop" in stratified systems, Mar. Ecol. Prog., 59, 1-17, https://doi.org/10.3354/meps059001, 1990.

Tiwari, S. P. and Shanmugam, P.: An evaluation of models for the satellite-estimation of phytoplankton absorption coefficients in coastal/oceanic waters, IEEE J. S. Top. Appl., 7, 364-371, https://doi.org/10.1109/JSTARS.2013.2252151, 2014.

Uitz, J., Claustre, H., Morel, A., and Hooker, S. B.: Vertical distribution of phytoplankton communities in open ocean: An assessment based on surface chlorophyll, J. Geophys. Res.-Oceans, 111, C8005, https://doi.org/10.1029/2005JC003207, 2006.

Uitz, J., Huot, Y., Bruyant, F., Babin, M., and Claustre, H.: Relating phytoplankton photophysiological properties to community structure on large scales, Limnol. Oceanogr., 53, 614-630, https://doi.org/10.4319/lo.2008.53.2.0614, 2008.
Van Heukelem, L. and Hooker, S.: The importance of a quality assurance plan for method validation and minimizing uncertainties in the HPLC analysis of phytoplankton pigments, Phytoplankton Pigments, 5, 195-256, https://doi.org/10.1017/CBO9780511732263.009, 2011.

Van Heukelem, L. and Thomas, C. S.: Computer-assisted high-performance liquid chromatography method development with applications to the isolation and analysis of phytoplankton pigments, J. Chromatogr. A, 910, 31-49, https://doi.org/10.1016/S0378-4347(00)00603-4, 2001.

Vidussi, F., Claustre, H., Manca, B. B., Luchetta, A., and Marty, J. C.: Phytoplankton pigment distribution in relation to upper thermocline circulation in the eastern Mediterranean Sea during winter, J. Geophys. Res.-Oceans, 106, 19939-19956, https://doi.org/10.1029/1999JC000308, 2001.

Wang, S., Ishizaka, J., Hirawake, T., Watanabe, Y., Zhu, Y., Hayashi, M., and Yoo, S.: Remote estimation of phytoplankton size fractions using the spectral shape of light absorption, Optics Exp., 23, 10301-10318, https://doi.org/10.1364/OE.23.010301, 2015.

Wang, S. Q., Ishizaka, J., Yamaguchi, H., Tripathy, S. C., Hayashi, M., Xu, Y. J., Mino, Y., Matsuno, T., Watanabe, Y., and Yoo, S. J.: Influence of the Changjiang River on the light absorption properties of phytoplankton from the East China Sea, Biogeosciences, 11, 1759-1773, https://doi.org/10.5194/bg-11-1759-2014, 2014.

Yamaguchi, H., Kim, H. C., Son, Y. B., Sang, W. K., Okamura, K., Kiyomoto, Y., and Ishizaka, J.: Seasonal and summer interannual variations of SeaWiFS chlorophyll a in the Yellow Sea and East China Sea, Prog. Oceanogr., 105, 22-29, https://doi.org/10.1016/j.pocean.2012.04.004, 2012.

Zhang, H., Qiu, Z., Sun, D., Wang, S., and He, Y.: Seasonal and Interannual Variability of Satellite-Derived Chlorophyll $a$ (2000-2012) in the Bohai Sea, China, Remote Sensing, 9, 582, https://doi.org/10.3390/rs9060582, 2017.

Zhang, J., Liu, S., Ren, J., Wu, Y., and Zhang, G.: Nutrient gradients from the eutrophic Changjiang (Yangtze River) Estuary to the oligotrophic Kuroshio waters and re-evaluation of budgets for the East China Sea Shelf, Prog. Oceanogr., 74, 449-478, https://doi.org/10.1016/j.pocean.2007.04.019, 2007.

Zhou, M. J., Shen, Z. L., and Yu, R. C.: Responses of a coastal phytoplankton community to increased nutrient input from the Changjiang (Yangtze) River, Cont. Shelf Res., 28, 1483-1489, https://doi.org/10.1016/j.csr.2007.02.009, 2008. 